\title{
Teoretické vymedzenie konceptu globálnej občianskej spoločnosti v kontexte medzinárodných vzt’ahov a medzinárodného práva
}

L'ubica Saktorová *

DOI: https://doi.org/10.24040/sap.2020.7.4.337-383

\begin{abstract}
Abstrakt:
SAKTOROVÁ. Lubica: Teoretické vymedzenie konceptu globálnej občianskej spoločnosti v kontexte medzinárodných vzt’ahov a medzinárodného práva. Štúdia analyzuje filozofické a teoretické východiská a prístupy k skúmaniu konceptu globálnej občianskej spoločnosti, prezentuje súhrnný konspekt súčasných prelínajúcich sa výskumov globálnej občianskej spoločnosti s ciel’om teoreticky demonštrovat' a verifikovat' jej relevanciu pre d’alšie vedecké skúmanie v odbore medzinárodných vzt'ahov, ale aj $\mathrm{v}$ odbore medzinárodného práva. Prvú čast' štúdie tvorí vymedzenie a definovanie teoretického rámca liberalizmu, konkrétne politického liberalizmu, o ktorý sa d’alší výskum témy opiera. Nasleduje záber na historicko-filozofický exkurz ideí a vnímania tohto konceptu v priereze niekol'kých storočí a v súčasnosti, podporené exemplifikáciou v podobe jedno prípadovej inštrumentálnej štúdie. Výstupom je teoretické vymedzenie, charakteristické znaky a definícia pojmu globálna občianska spoločnost'. Záverom je možné deklarovat', že uvedený koncept je možné chápat' ako samostatnú výskumnú kategóriu s vlastnou definíciou, znakmi, vplyvom, historicky a filozoficky deklarovanou a verifikovanou relevanciou.
\end{abstract}

\section{Kl’účové slová:}

globálna občianska spoločnost', teoretická výskumná kategória, medzinárodné vzt’ahy, medzinárodné právo, globalizácia, vplyv

\section{Theoretical Determination of the Concept of Global Civil Society in Context of the International Relations and the International Law}

\begin{abstract}
:
SAKTOROVÁ, Lubica: Theoretical Determination of the Concept of Global Civil Society in Context of the International Relations and the International Law. The study analyses the philosophical and theoretical background and approaches to the exploration of the concept of global civil society. Moreover, it presents a comprehensive conspectus of the current overlapping research of global civil society with the aim of theoretically demonstrating and verifying its relevance for further scientific research in the field of international relations
\end{abstract}

\footnotetext{
JUDr. L’ubica Saktorová PhD., LL.M, M.A., odborná asistentka. Katedra medzinárodného, európskeho práva a právnej komunikácie. Právnická fakulta Univerzity Mateja Bela v Banskej Bystrici.
} 


\begin{abstract}
but also in the field of international law. The first part of the study focuses on the demarcation of the theoretical framework of liberalism, namely political liberalism, on which further research of the subject relies. This is followed by an excursion over the historical - philosophical ideas and perceptions of this concept in the cross-section of several centuries and at present. The thesis are exemplified in the form of a single-case instrumental study. The outcome is theoretical definition, characteristics and definition of the concept of global civil society. In conclusion, it can be stated that this concept can be understood as a separate and unique research category with its own definition, features, influence, historically and philosophically declared relevance.
\end{abstract}

\title{
Key words:
}

global civil society, theoretical research category, international relations, international law, globalization, influence

\section{Úvod}

Termín občianska spoločnost' nie je novým výrazom ani invenciou modernej politickej vedy. Občianska spoločnost' sa vyvinula pôvodne ako istý prostriedok na zapojenie jednotlivcov do politických diskusií, do diskusií o veciach verejného záujmu. V dobe antiky sa grécki filozofi zaoberali aj problémami obklopujúcimi komunálny život a vžitými rozpormi medzi potrebami jedincov a potrebami spoločnosti. Medzi navrhnutými riešeniami sa často objavovala téza o racionálnom dialógu medzi tými, ktorí rozhodovali a tými, o ktorých rozhodované bolo, teda občanmi, ktorí sa môžu dobrovol’ne a neformálne zapojit do politického diskurzu. $\mathrm{V}$ dobe osvietenstva bola myšlienka o občianskej spoločnosti po prvýkrát zaradená do kontextu verejnej sféry, kde sa súkromné záujmy jednotlivcov zjednocujú s univerzálnymi morálnymi záväzkami, rešpektujúc pri tom autoritu štátu. Podmienky spravodlivosti, práva a pokoja $\mathrm{v}$ spoločnosti boli po prvýkrát naviazané na dobre fungujúcu občiansku spoločnost', dokonca nie len v zmysle národnom, ale univerzálnom. Verejný diskurz o občianskej spoločnosti a jej globálnej verzie bol obnovený po ukončení studenej vojny, v súvislosti s akceleráciou globalizačných procesov na strane jednej a tiež $\mathrm{s}$ konkrétnymi politickými zmenami v Latinskej Amerike a strednej a východnej Európe v druhej polovici 20. storočia. Tlak na zmenu politického režimu $\mathrm{v}$ týchto oblastiach začal byt' $\mathrm{v}$ akademických a vedeckých kruhoch často pripisovaný aktivitám $\mathrm{v}$ nevládnom, občianskom sektore $\mathrm{v}$ konjunkcii a s podporou sietí medzinárodných aktivistov. O sile aktérov globálnej občianskej spoločnosti sa začalo hovorit čoraz intenzívnejšie. Počet motivovaných jednotlivcov, lokálnych a regionálnych mimovládnych združení, medzinárodných nevládnych organizácií, skupín, asociácií s vôl'ou ovplyvňovat' existujúce systémy a inštitúty začal exponenciálne rást' a penetrovat' do rozličných sfér verejného života. Primárnym verejným záujmom v spoločnosti s historickou relevanciou, no s nespochybnitel'nou relevanciou aj v súčasnosti však zostáva unifikácia záujmov jednotlivcov so záujmami celku a eliminácia nepokojov a napätia, ktoré $z$ daného vžitého rozporu vznikajú.

Problematiku, ktorá z uvedeného vyplýva možno rámcovo uviest' ako otázku, kto je globálna občianska spoločnost', kto sú jej členovia, aktéri, ktorí disponujú potenciálom ovplyvňovat' rozhodovacie procesy na medzinárodnej úrovni. Unifikovaná, uzav- 
retá a všeobecne akceptovaná definícia občianskej spoločnosti/ globálnej občianskej spoločnosti neexistuje. $\mathrm{K}$ danej tematike dodnes neexistuje unifikovaný, uzavretý a všeobecne akceptovaný pojmový aparát - na úrovni domácich, zahraničných teoretikov, ale ani l'udí z praxe, orgánov štátnej správy, či samej občianskej spoločnosti. Občianska spoločnost' je neustále meniacou sa veličinou, živou, nie jasne uchopitel'nou entitou, ktorú aj výstupy akademických výskumov kategorizujú s vel'kou opatrnostou a s akcentom na subjektívne vnímanie konkrétneho skúmaného javu. Napriek tomu však snahy o jej nocionálne vymedzenie pretrvávajú. Témou tejto štúdie je práve teoretická klasifikácia globálnej občianskej spoločnosti v kontexte medzinárodných vzt’ahov a medzinárodného práva.

Ciel’om práce je snaha o vedeckú kvalifikáciu fenoménu, ktorý súvisí s aktivitami aktérov občianskej spoločnosti s globálnym dosahom, konkrétne teoreticky demonštrovat' a verifikovat' relevanciu tohto konceptu pre d'alšie vedecké skúmanie $\mathrm{v}$ odbore medzinárodných vzt'ahov, ale aj v odbore medzinárodného práva. Nakol'ko $\mathrm{v}$ rámci uvedenej témy stále neexistuje stabilný pojmový aparát, okrem priblíženia a podrobnej analýzy vybranej problematiky má práca ambíciu prispiet' aj ku teoretickej konceptualizácii globálnej občianskej spoločnosti ako samostatnej výskumnej kategórie v medzinárodných vzt’ahoch.

Z hl'adiska štruktúry je štúdia rozdelená do štyroch nosných častí, ktoré obsahovo sledujú naplnenie stanoveného ciel'a: úvodná čast' analyzuje teoretické východiská a prístupy k skúmaniu konceptu globálnej/ občianskej spoločnosti. Úvod tvorí vymedzenie a definovanie teoretického rámca liberalizmu, konkrétne politického liberalizmu, o ktorý sa d’alší výskum témy opiera. Nasledujúca čast' je zameraná na historicko - filozofický exkurz ideí a vnímania tohto konceptu v priereze niekol'kých storočí. Taktiež bude určený moment, ktorý je vedeckými a akademickými osobnost’ami vo výskume považovaný za klúčový pri obnove legitimity a potenciálu občianskej spoločnosti. Je nutné zdôraznit', že pri praktických štúdiách nie je možné oddelit' občiansku a globálnu občiansku spoločnost', nakol'ko empiricky sú tieto dve entity navzájom prepojené, naviazané. Globálna občianska spoločnost' je priamo derivovaná a viazaná na život v občianskej spoločnosti na úrovni lokálnej, národnej, či regionálnej. Pre účely tejto práce preto pojem občianska spoločnost' predstavuje pojem generalizujúci, všeobecnejší ako s pridaním adjektíva globálna. Nezrovnalosti, nejednotnost' a určitá nekomplexnost', ktoré sprevádzajú 'rodičovský' koncept sú následne paralelne prenášané do konceptu 'dcérskeho'. Je tiež dôležité spomenút', že v rámci exkurzu výskumov budeme operovat' najmä s tými, ktoré sú mladšie ako 20 rokov, t.j. od roku 2001. V d’alšej časti štúdie sa pokúsime o vlastnú rámcovú definíciu konceptu, ktorá bude analyticky derivovaná tak zo súčasne prebiehajúcich výskumov o implikácii vplyvov občianskej spoločnosti na medzinárodne rezonujúce problematiky, ako aj z integrálneho fenoménu globalizácie. Prostredníctvom suplementárnych analýz súčasne prebiehajúcich výskumov v problematike a selekcii vhodného náhl'adu bude abstrahovaná definícia pojmu globálna občianska spoločnost', jej charakteristické znaky, budú tiež vymedzené predpoklady pre schopnost' jej aktérov ovplyvňovat' rozhodovacie procesy na medzinárodnej úrovni. Uvedené tézy budú záverom exemplifikované jednoprípadovou, inštrumentálnou štúdiou založenia Medzinárodného trestného súdu v holandskom Haagu. 


\section{Politický liberalizmus ako teoretický rámec výskumu globálnej občianskej spoločnosti}

Globálna občianska spoločnost' vo všetkých sférach spoločenského, ako aj politického života na úrovni lokálnej, regionálnej a medzinárodnej je téma, ktorá za posledných 30 rokov čoraz viac rezonuje nielen v rôznych akademických polemikách. Spoločnost' je tu ponímaná v zmysle občianskej spoločnosti, globálnej spoločnosti, či svetovej občianskej spoločnosti, ktorej význam má mnoho podôb a definícií. Samotná práca však bude operovat's uvedenými pojmami viac, ako s inými možnými termínmi v danej problematike. ${ }^{1}$ Vplyv globálnej občianskej spoločnosti na medzinárodnú politiku, vzt’ahy medzi štátmi, či dokonca na tvorbu medzinárodného práva je témou s liberálnym, $v$ určitých prípadoch je možné hovorit' až o striktne idealistickom podtexte. Tematicky zapadá do rámca liberálnej teórie $\mathrm{v}$ medzinárodných vzt’ahoch, konkrétne teórie politického liberalizmu v gescii Johna Rawlsa a Andrewa Moravcsika.

Súčasné poňatie liberalizmu ako teórie v medzinárodných vzt’ahoch nie je možné vymedzit' a definovat' unifikovaným spôsobom. Podla niektorých autorov je liberalizmus možné vymedzit' ako ideológiu, ktorá vo svojej klasickej podobe spája slobodu so živelnost'ou, kde sa živelnost' chápe ako najlepšia cesta k sebausporiadaniu spoločnosti. ${ }^{2}$ Iní vymedzujú liberalizmus vo vzt’ahu k teóriám realizmu, či konzervativizmu. ${ }^{3}$ Ďalej je možné liberalizmus charakterizovat' ako politickú teóriu, ktorá spočíva na spoločnom duchovnom prúde osvietenstva a racionalizmu, kde je základný princíp osvietenstva mohutným príklonom k oslobodeniu od balastu tradície a útlaku autority. Hybnou silou je l’udský rozum, ktorý má vo filozofii racionalizmu centrálnu úlohu $\mathrm{v}$ protiklade $\mathrm{k}$ dogmatickým názorom. Podl’a L. T. Sargenta majú liberálne teórie tieto črty: 1. majú tendenciu favorizovat' zmeny, 2. spočívajú na viere v l'udský rozum, 3 . sú náchylné používat' vládnu moc na zlepšenie podmienok života l’udí, 4. preferujú slobodu jednotlivcov, 5. sú ambivalentné vo vzt’ahu k l'udskej povahe. ${ }^{4}$

V každom prípade je však možné tvrdit', že sa liberalizmus dotýka širokého spektra súvisiacich myšlienok a teórií, ktoré považujú individuálnu slobodu za najdôležitejší politický ciel'. Je však aj smerom, v ktorom je v rôznej miere prítomných týchto 5 prvkov: 1 . viera $v$ pokrok, 2 . individualizmus, 3 . preferencia slobody, 4 . akceptácia súkromného vlastníctva, 5 . obmedzenie funkcií štátu a moci štátneho aparátu. ${ }^{5}$

1 Napríklad globálne sociálne hnutia (Cohen - Rai, 2004), transnacionálne sociálne hnutia (Smith, 1997), svetová spoločnost', sociálny aktéri (Czempiel, 1999, s. 149-151), siete skupín v medzinárodnej politike či transnacionálne advokátske siete (Keck - Sikkink, 1998) globálne občianske združenia, či medzinárodná alebo transnacionálna občianska spoločnost', taktiež medzinárodná občianska spoločnost' či medzinárodné, nevládne organizácie (Ghils 1992, 417 431), nový multilateralizmus (Schechter, 1998) etc.

2 KREJČÍ, O.: Mezinárodní politika. Praha: Ekopress, 2010, s. 674.

3 BERGSTRASSER, L.: Geschichte der Politischen Parteien in Deutschland. In: KULAS̆IK, P.: Liberalizmus. Banská Bystrica: UMB, 1998, s. 6.

4 SARGENT, L. T.: Contemporary Political Ideologies. In: KULAŠIK, P.: Liberalizmus. Banská Bystrica: UMB, 1998, s. 6.

5 KULAŠÍK, P.: Liberalizmus. Banská Bystrica: UMB, 1998, s. 6. 
Ekonomický liberalizmus v tomto kontexte a ekonomickej sfére v užšom zmysle vyzdvihuje práva jednotlivca urobit' l'ubovol'né rozhodnutie v rámci výkonu svojej práce a použitia vlastných zdrojov a príjmov, pokial je rešpektovaná sloboda, vlastníctvo a zmluvné práva ostatných. Sociálny liberalizmus vo všeobecnosti rozširuje túto myšlienku do všetkých aspektov života, okrem života politického. Požaduje pri tom slobodu myslenia a vyjadrovania, náboženského vierovyznania, slobodu zhromažd’ovania a združovania, sexuálnej orientácie, či spôsobu života, všetko pod podmienkou, že akákol'vek parciálna sloboda alebo právo jedinca nesmie zasahovat' a poškodzovat' práva a slobody iných. Ide tiež o celý hmotnoprávny koncept ludských práv a slobôd, ktorý sa tvoril a vyvíjal paralelne na báze liberálnych ideí. Práva a slobody samozrejme nie sú neobmedzené, nie je možné konat' čokol'vek, ani disponovat' právom na úplnú vol’nost' konania. Výsledkom takýchto neobmedzených slobôd by bolo konštantné ohrozenie zo strany iných jednotlivcov. Sloboda každého sa zvyšuje práve skutočnost'ou, že jednotlivci spoločne a vzájomne uznávajú rovnaké obmedzenia, ktorých obsahom je vylúčenie foriem násilia a podvodného konania tak, aby interakcie medzi jednotlivcami prebiehali so slobodným súhlasom každej dotknutej strany. Nátlakové, či represívne opatrenia sú povolené len v zákonom stanovených prípadoch a situáciách proti tomu, kto legitímne akceptované obmedzenia porušuje.

Politický liberalizmus nie je možné chápat' v rovnakých intenciách, ked’že rozhodnutia v politickej sfére musia, podla predpokladu, byt' kolektívne a záväzné pre všetkých členov spoločnosti. Ideologické základy politického liberalizmu však zostávajú rovnaké. Okrem zákazu bránit' v slobode iným, nemá žiadnu špeciálnu morálnu doktrínu o tom, podla akých princípov by sa l'udia mali riadit’ vo svojich osobných životoch. Politický liberalizmus potvrdzuje právo jednotlivcov na vol'bu vlastných zástupcov v periodických vol'bách, ako aj na právo združovat' sa v politických zoskupeniach podla vlastnej vôle tak, aby mali možnost' podporovat' politické stratégie a ciele strany, hnutia, respektíve slobodného zoskupenia, či združenia podl’a svojho výberu. Podl'a Johna Rawlsa, ktorého diela Teória spravodlivosti (1971) a Politický liberalizmus (1997) tvoria intelektuálny základ pre d'alší rozvoj vyššie uvedených myšlienok, je teóriu politického liberalizmu možné nazvat' pokusom o špecifikovanie podmienok, za akých by mohli v dobre organizovanej spoločnosti rozumných l'udí koexistovat' jednotlivci a skupiny, ktoré majú odlišné názory zakladajúce sa na rôznom pôvode, zázemí, minulosti, viere, či názoroch. Taktiež je nutné zdôraznit', že sa jedná o spoločnost' slobodných a rovnoprávnych občanov, ,ktorí sú zásadne rozdelení rozumnými, avšak nezlučitelnými náboženskými, filozofickými a morálnymi doktrínami“" ${ }^{6}$ Liberalizmus, tak ekonomický, sociálny ani inštitucionálny nehovorí nič o tom, aká iniciatíva, metódy, či politická stratégia je $\mathrm{v}$ danom kontexte na dosiahnutie ciel'ov v diferencovanej spoločnosti najvhodnejšia.

Podla Rawlsa je tu nutný určitý „prekrývajúci sa konsenzus“ ako minimálny súbor hodnôt, princípov a noriem, na ktorých by sa, v záujme efektívneho a spravodlivého spravovania vecí verejných, mohli a mali dohodnút' všetci členovia spoločnosti, bez ohl'adu na ideológiu, náboženstvo alebo sociálne postavenie. ${ }^{7}$ Hladanie takého „morálneho minima“ zamestnávalo náboženských myslitel’ov a politických filozofov vo všetkých dobách a všetkých kultúrach.

6 RAWLS, J.: Politický liberalizmus. Prešov: Slovacontact, 1997, s. xiii

7 Ibid. 
V súčasnosti je možné tvrdit', že politický liberalizmus je reflektovaný systémom legitímnych inštitúcií, ktoré na jednej strane poskytujú určité garancie vládnej zodpovednosti voči l'udu a na strane druhej limitujú vládnu moc v narušení alebo ohrození individuálnych slobôd. Štandardným a úplne základným systémom vytvoreným a legitimovaným počas minulých storočí na tento účel je ustanovenie a.) parlamentu, ako zákonodarnej moci, ktorý proporcionálne zodpovedá preferenciám l'udu a rozloženiu politických síl na základe slobodných volieb; b.) vlády, ktorú tvoria reprezentanti vít’azných politických strán a hnutí, ako legitímne utvorený agregát s výkonnými právomocami. Nakoniec je systém ochrany individuálnych práv, slobôd a ústavných garancí́ tvorený; c.) mocou súdnou, ktorá pozostáva z nezávislého aparátu súdnych orgánov a inštancií zabezpečujúcich priamu realizáciu spravodlivosti v prípade, ked' sú pravidlá vo forme právneho poriadku štátu narušené.

Centrálny náhl'ad, ktorý je zdiel’aný väčšinou liberálnych teoretikov sa zakladá na premise, že štáty sú vsadené do domácej, ako aj globálnej občianskej spoločnosti, ktorá zásadne a rozhodne obmedzuje ich činnost'. ${ }^{8}$ Podl'a Moravcsika je základ liberálnej teórie aplikovanej na medzinárodnú politiku možné vyjadrit' vo forme troch predpokladov: Prvým je tvrdenie, že primárnymi aktérmi v politike sú členovia domácej spoločnosti, teda jednotlivci a privátne inštituované skupiny, ktoré presadzujú svoje autonómne záujmy. Politika tak domáca, ako aj zahraničná je vložená do kontextu spoločenských interakcií, ktoré obmedzujú zámery a možnosti vládnej moci. Spoločnost’ je tu tvorená samostatnými jednotlivcami s vlastnou identitou, ktorí sa snažia o vytvorenie skupín, združení, organizácií či iných zoskupení s podobnými alebo aj s rovnakými záujmami a ciel'mi, s vidinou dosiahnutia svojich sociálnych alebo politických ciel'ov. ${ }^{9}$

Druhým predpokladom podla Moravcsika je skutočnost', že všetky vlády reprezentujú určitý segment, respektíve čast' domácej spoločnosti, ktorej záujmy sú reflektované určitým smerovaním štátnej politiky. Spoločnost' je tu vymedzená v zmysle agregátu autonómnych, samostatných jednotlivcov a dobrovol’ných skupín, pričom liberálne politické teórie priznávajú ústrednú rolu domácim inštitúciám, ktoré spájajú štát a spoločnost'. Tieto inštitúcie tu fungujú ako mechanizmy na prezentovanie spoločenských záujmov. Pre liberálov je vzt’ah principála a agenta, ako populácie a štátu centrálnou otázkou, rozsah reprezentatívnosti je dôležitou veličinou, ktorá vysvetl'uje štátnu politiku. Predpokladom je, že štát tu reprezentuje len určitú vzorku alebo súbor sociálnych skupín a nie celú populáciu..$^{10}$

Tretím predpokladom vyjadrujúcim aplikáciu liberálnej teórie na medzinárodnú politiku je, že v prípade vzniku medzinárodného konfliktu je to práve správanie štátov a nadviazané kooperácie, ktoré reflektujú podstatu a konfiguráciu štátnych preferencií. Pre liberálov je nie sila štátu, ale jeho účel, ciele a zámery určujúcim faktorom vo svetovej politike. Realisti často uvažujú o liberálnej teórií len v intenciách, kedy sú zámery a ciele štátov konvergentné, dokonca úplne harmonizované. No tak, ako liberáli nepredpokladajú harmonizáciu všetkých individuálnych záujmov, rovnako odmietajú možnost' automatickej konvergencie záujmov štátov. ${ }^{11}$

8 MORAVCSIK, A.: Liberalism and International Relations Theory. 1992, s. 6.

9 Ibid.

10 Ibid.

11 Ibid. 
V zmysle uvedeného je možné normatívne globálnu občiansku spoločnost' prezentovat' ako súbor aktérov, inštitúcií a praktík, ktoré reflektujú takto nastavenú liberálnu paradigmu. Globálna občianska spoločnost' poskytuje na jednej strane priestor pre presadzovanie individuálnych záujmov, no v rámci vlastnej heterogénnosti tieto záujmy subsumuje k záujmom jej jednotlivých súčastí. V rámci vlastnej inherentnej civilizovanosti presadzuje hodnoty tolerancie, kooperácie a nenásilia. Stvárňuje pritom nie len liberálne poňatie demokracie, slobody, participácie a občianstva na globálnej úrovni, ale taktiež pluralitu, rôznorodost', individuálne práva a sebarealizáciu.

Pre d'alší výskum bolo potrebné determinovat' základné atribúty teoretického rámca, o ktoré sa predpoklady stanovené v práci opierajú. Uvedené síce delimituje len skutočne teoretické vymedzenie, istý vzorec, či optiku ponímania problematiky, navodzuje však vel'mi zásadné oporné body, v súlade s ktorými bude d'alší normatívny a empirický výskum vedený.

\section{Historická genéza konceptu občianskej spoločnosti}

Idea konceptu občianskej spoločnosti, ako 'rodičovského' konceptu globálnej občianskej spoločnosti je hlboko zakorenená v tradícii politického myslenia. Kým bola do obdobia osvietenstva primárne zosobnená so štátom a spoločnost'ou politickou, na konci 18. storočia je pojem čoraz viac používaný na pomenovanie sociálnych javov a sociálnych aktivít občanov mimo sféru štátneho aparátu, či rodiny. Nasledovná čast' je venovaná konceptuálnemu prierezu historického vývoja, či už samotného termínu občianska spoločnost', ako aj neskôr jeho obsahu, ktorý sa postupom času v dejinách menil a formoval do svojej súčasnej, globálnej, 'dcérskej' podoby. Identifikáciou filozofických a historických podmienok, na základe ktorých vízia občianskej spoločnosti v minulosti vznikla, je možné dotvorit' ucelenejší obraz o jej politickej a sociálnej relevancii v súčasnom globalizovanom svete.

\section{Starovek}

Pojem občianskej spoločnosti historicky vychádza z termínu, ktorý ako prvý v starovekom Grécku použil Aristoteles, koinonía politiké, politická asociácia alebo združenie. ${ }^{12}$ Koinonía politiké bola pre neho nezávislou a samostatnou asociáciou slobodných, rovných a podobne zmýšl'ajúcich osôb, ktorých spája ethos, súbor noriem a hodnôt zdiel'aných a ctených členmi tejto spoločnosti. Ako uvádza Cohen a Arato, koinonía politiké však bola asociácia medzi mnohými; termín koinonía bol používaný na vykreslenie všetkých foriem a druhov l'udských združení a spolkov, ktorých členov spájali spoločné hodnoty, podobný záujem o konkrétne skutočnosti a vzájomné zdiel’anie názorov, postrehov a skúseností. ${ }^{13}$ Kým však rôzne koinonía mali svoje ciele, koinoía politiké mala ciele najvyššie: prepájat' verejné kolektívne aktivity tak, aby slúžili na dosiahnutie dobrého života $v$ spoločnosti. Tento druh združenia spájal jednotlivcov nie v duchu naplnenia egoistických potrieb v spoločenskom živote, ale skôr ako partnerstvo jednotlivcov s účelom robenia dobrých veci pre spoločnost' ako celok.

12 LAYNE, CH Kant or Cant: The Myth of the Democratic Peace. In: International Security. 2014. vol. 19 , no. 2. s. 5-49.

13 ARATO, A. - COHEN, J. L.: Civil Society and Political Theory. MIT Press, 1994, s. 84. 
Historické korene termínu je d’alej možné nájst' v diele Ciceróna, De Re Publica I. ${ }^{14} \mathrm{v}$ starom Ríme. Tu je podobne viazaný na koncept, $\mathrm{v}$ ktorom je táto spoločnost' synonymom pre spoločnost' politickú: „societas civilis sive res publica“/ „občianska spoločnost' alebo vec verejná“, existencie spoločenstva l'udí, ktorí sa spájajú pre spoločné dobro. V takto samoregulovanej spoločnosti l’udia medzi sebou interagujú ako rovné a slobodné osoby prostredníctvom práva, nie sily ani nátlakom, ani podriadením. ${ }^{15}$ Cicerónove prirovnanie societas civilis $\mathrm{k}$ res publica, teda $\mathrm{k}$ veci verejnej/ spoločnosti politickej, ako aj Aristetolova koinoía politiké zostali počas storočí hlavnou črtou historickej konceptualizácie občianskej spoločnosti v nasledujúcich storočiach. Tento termín bolo neskôr možné evidovat' v priereze európskej histórie, no určitej výnimočnosti sa mu dostalo až v období 17. a 18. storočia, ked' osvietenskí filozofi rozjímali o základoch vznikajúcich národných štátov. Kl'účovým predpokladom pre vznik občianskej spoločnosti však bolo krestanské ponímanie l'udskej rovnosti. ${ }^{16}$

\section{Novovek}

Výraz societas civilis bol využívaný v dobe osvietenstva na vyjadrenie idey, že vládca nemá božské absolútne právomoci, ale sú to práve l'udia, ktorí sa dobrovol'ne spájajú a vyjednávajú hypotetickú, spoločenskú zmluvu na formovanie spoločnosti, v ktorej sú práva a povinnosti občanov a panovníka jasne zadefinované. Napriek tomu je však v tejto dobe termín občianska spoločnost' nerozlučne spätý s chápaním štátu, štátneho usporiadania. Termín 'občianska spoločnost' je pre väčšinu filozofov až do obdobia 19. storočia považovaný dokonca za synonymum pre termín 'štát'.

Pre Thomasa Hobbsa, jedného z prvých filozofov, ktorý sa téme venoval, nebol koncept nezávislej občianskej spoločnosti benefitom. Občianska spoločnost' bola pre neho prostriedkom pre vytvorenie autoritatívneho štátu, kde je spoločnost' na základe spoločenskej zmluvy absolútne podriadená panovníkovi. Hobbes uprednostňoval nelimitovanú, absolútnu moc štátu ako jediný možný spôsob vlády pre udržanie mieru, pre zabránenie sporových situácií a tlmenie l'udskej konfliktnej povahy. Akékol'vek aktivity neštátnych aktérov vnímal ako presadzovanie sebeckých ciel'ov, a teda neželané javy, ktoré by mali byt' štátom potlačené. ${ }^{17}$

Podobné, no mierne modifikované názory zdiel'al aj d’alší predstavitel' tohto obdobia, John Locke. Ten je považovaný aj za ideologického zakladatel'a liberalizmu a bol často vnímaný ako klúčcová postava rozvoja koncepcie l’udských práv a slobôd vo filozofii. Tvrdil, že každý človek má právo na život, slobodu a majetok. Tieto názory zakladal na myšlienke racionálneho, rovnocenného človeka a prirodzených práv, ktoré sú mu, ako ludskej bytosti, poskytované Bohom. Také štátne zriadenie, ktoré

14 Cicero. De Re Publica I., xxxii, 49: Lat: Quare cum lex sit civilis societatis vinculum, ius autem legis aequale, quo iure societas civium teneri potest, cum par non sit condicio civium? Si enim pecunias aequari non placet, si ingenia omnium paria esse non possunt, iura certe paria debent esse eorum inter se, qui sunt cives in eadem re publica. Quid est enim civitas nisi iuris societas civium?

15 AXTMANN, R.: Liberal Democracy Into the Twenty-first Century: Globalizationa, Integration and the Nation-state, Political analyses. Manchester University Press, 1996, s. 54.

16 ANHEIER, H. K. - KALDOR, M. - GLASIUS, M.: Global Civil Society 2001, s. 12.

17 LEVIATHAN, T. H.: Locke vs. Hobbes. [online]. 2005, [cit. 2018-12-28]. 
súvisle porušovalo prirodzené práva bolo považované za tyraniu a teda stratilo legitimitu vládnut. ${ }^{18}$ V diele Dve rozpravy o vláde (1690) sa do centra Lockovej pozornosti dostáva vláda, ktorej primárnu funkciu vidí v službe a v ochrane jednotlivcov žijúcich v občianskej spoločnosti. Jednotlivci súhlasia s obmedzením svojho konania tým, že udelia vláde možnost' konat' $\mathrm{v}$ ich prospech, pri ochrane ich majetku a prirodzených práv. $Z$ dôvodu vzájomných výhod vstupujú l’udia do zväzku so štátom a uzatvárajú s ním pomyselnú spoločenskú zmluvu, na základe ktorej sa ochotne vzdávajú niektorých svojich slobôd a konania a na oplátku získavajú pocit bezpečia a stability vo svojich každodenných životoch. Locke uvádza, že l'udské bytosti, ako bolo dané prírodou sú všetky slobodné, rovné a nezávislé, nik nesmie byt' pozbavený svojho majetku, ako nesmie byt' podrobený politickej moci bez vlastného súhlasu. Jediný spôsob, kedy sa niekto zbavuje vlastnej prirodzenej slobody a viaže ju na občiansku spoločnost' je súhlas $\mathrm{s}$ iným človekom zjednotit' sa $\mathrm{v}$ komunite pre ich komfortné, bezpečné žitie $\mathrm{v}$ mieri medzi inými, v pokojnom užívaní vlastného majetku a väčšom bezpečí voči tým, ktorí jej súčast'ou nie sú. ${ }^{19}$

Obaja uvedení filozofi prezentovali myšlienku systému, v ktorom by bolo možné zabezpečit' mierové spolužitie medzi l'ud'mi prostredníctvom sociálnych paktov a zmlúv. Občiansku spoločnost' považovali za komunitu, ktorá udržiava občiansky život; sféru, kde sa občianske cnosti, hodnoty, práva a slobody odvíjajú od prirodzených práv jednotlivcov. Občiansku spoločnost' však nepovažovali za entitu, ktorá by bola zásadne oddelená od štátu. Naopak, práve zdôrazňovali ich koexistenciu. Prístupy Hobbsa a Locka v analýzach sociálnych vzt’ahov boli značne ovplyvnené skúsenost’ami obdobia, v ktorom žili. Ich pokusy o vysvetlenie l'udskej podstaty, prirodzených práv, vytvorenia vlády, či sociálnej zmluvy medzi občanmi a štátom podkopávali základy dovtedy existujúcej teórii božských práv. V rozpore s touto teóriou, Hobbes a Locke tvrdili, že l'udia si môžu navrhnút', vybrat' a stanovit' politickú moc. Občianska spoločnost' pre oboch zostávala spoločnost’ou pacifistickou; spoločnost'ou, v ktorej bolo použitie sily zo strany jednotlivca zakázané. ${ }^{20}$ Tieto myšlienky mali neskôr vel'ký vplyv na myslitel'ov obdobia osvietenstva.

Jedným z kritikov názorov o občianskej spoločnosti, ktorá je tvorená striktnými pravidlami na základe podriadenia sa vo forme spoločenskej zmluvy medzi štátom a jednotlivcami bol Jean Jacques Rousseau. Vo svojom diele Du contrat social (1762) skôr hovorí o dobre riadenej spoločnosti, ktorá tvorí základ pre mier a harmonické spolužitie l'udí a to na základe všeobecnej vôle, la volonté générale, ktorá by mala byt' nadradená vôli jedinca. Na rozdiel od Hobbsa, ktorý vidí fungujúcu spoločnost' ako výsledok absolútnej vlády suveréna, ktorého moc pochádza od l'udí, Rousseau vidí jediné "absolútno"v suverenite l'udí a zákona. ${ }^{21}$ Vo všeobecnosti je však možné konštatovat', že v tomto období šlo stále o spoločnost' vo forme spoločenského zriadenia, určitej formy vlády. Synonymom pre súčasné chápanie občianskej spoločnosti vo vtedajšej dobe sú skôr pomenovania les associations partielles, či la société partiel-

18 DONNELLY, J.: Universal Human Rights in Theory and Practice. Cornell University Press, 2003

19 LOCKE, J., 1963, s. 374-375.

20 AXTMANN, R.: Understanding Democratic Politics: An Introduction. Sage, 2003.

21 VIROLI, M. - HANSON, D.: Jean-Jacques Rousseau and the well-ordered society. Cambridge University Press, 2003. 
le, teda čiastkové združenia alebo spoločnosti. ${ }^{22} \mathrm{~V}$ diele Spoločenská zmluva (1794) Rousseau uvádza: „Je preto nevyhnutné, ak má byt' všeobecná vôl'a skutočne vyjadrená, aby v rámci štátu neexistovali žiadne čiastkové zoskupenia/spoločnosti a aby si každý občan robil vlastný názor, čo bol aj vznešený a jedinečný systém zavedený vel'kým Lykurgom. ${ }^{23}$ Ale ak existujú takéto čiastkové spoločnosti, je treba ich znásobit' a zabránit' tomu, aby boli nerovné tak, ako učinil Solon, Numa a Servius. Tieto opatrenia sú jediné, ktoré môžu zaručit', že bude všeobecná vôl'a natol'ko jasná, že sa l'udia $v$ žiadnom prípade nenechajú zmiast'." ${ }^{24}$ Autori ${ }^{25}$ často na základe tohto citátu z diela Spoločenská zmluva z roku 1794 uvádzajú, že je to práve Jean Jacques Rousseau, ktorý ako prvý odmietol život občianskej spoločnosti ako neprospešný pre štát, nakol'ko bráni resp. komplikuje vyjadrenie a akceptovanie všeobecnej vôle. Existuje však niekol'ko faktov, na základe ktorých je možné poukázat' na to, že sa Jean Jacques Rousseau téme venoval a život občanov v čiastkových združeniach nezavrhol úplne.

V prvom rade je možné poukázat' na referenciu, ktorá nasleduje po prvej vete a ktorou sa Rousseau odvoláva na úryvok z Machiavelliho diela Dejiny Florencie (1532). Ako škodlivé pre štát tu uvádza čiastkové spoločnosti vo forme sekty alebo strany, nie všetky spoločenské združenia. Hned' v nasledujúcej vete totiž hovorí tom, že pokial' sú v štáte takéto spoločnosti, čoho si je evidentne vedomý, potom by ich vplyv mal byt' vyrovnaný práve početnost'ou týchto skupín. Rousseau rozdel'uje tie asociácie, ktoré sú želané a tie, ktoré sú neželané a znepokojuje sa len tými, ktorých konanie je v rozpore s verejným záujmom: „Ale pokial’ sú záujmové skupiny a čiastkové asociácie formované na úkor celku, potom sa vôl'a každého takéhoto celku s ohl'adom na jeho členov považuje za všeobecnú, no s ohl'adom na štát je to stále len vôl'a čiastková. “26 Je teda zjavné, že vysvetl'uje jav, ktorý je v štáte neželaný a to sú tie zoskupenia, ktoré vlastnú vôl'u vydávajú za vôl'u všeobecnú. Tie asociácie, ktoré sa podiel'ajú na skutočnej všeobecnej vôli rovnocenným spôsobom ako jednotlivci, sú v štáte vítané.

Napriek tomu, že bol Rousseau kritický k určitým formám združení, uznáva, že iné môžu predstavovat' vel'ký prínos pre rozvoj l'udského potenciálu a pre tvorbu priaznivých podmienok pre dobrú vládu. Najdôležitejšia zo všetkých je ich rola vo vytváraní a udržiavaní štandardov v dobrom správaní sa a mravoch človeka. Tvrdí, že neexistuje dobre konštituovaný štát, $\mathrm{v}$ ktorom nie sú konvencie a dobré mravy priamo

22 ROUSSEAU, J.J.: Du Contract Social. Oeuvres. Ed. orne de fig. 1793, online

23 Poznámka uvedená v diele Spoločenská zmluva (1794): „V skutočnosti,“ vraví Machiavelli „sú divízie, ktoré sú pre Republiku škodlivé a sú také, ktoré sú výhodné. Tie, ktoré sa rozvíjajú v sekty a strany sú škodlivé, participácia na nich nie je výhodná. Ked’že nemôže zakladatel' Republiky pomôct' tomu, aby nepriatel'stvá vznikali, musí aspoň zabránit' jeho zhromažd’ovaniu sa v sektách.“ (Machiavelli N., 1532 Dejiny Florencie, Kniha VII)

24 ROUSSEAU, J.J.: Du Contract Social. Oeuvres. Ed. orne de fig. 1793, online, s. 204.

25 COLLETTI, L.: Rousseau as Critic of Civil Society. From Rousseau to Lenin: Studies in Ideology and Society. New York: NY university press, 1975, s. 143-195; PELED, Y.: Rousseau's Inhibited Radicalism: An Analysis of His Political Thought in Light of His Economic Ideas.In: American Political Science Review. 1980, vol. 74, n.4, s.1034-1045; VIROLI, M. - HANSON, D.: Jean-Jacques Rousseau and the'well-ordered society. Cambridge University Press, 2003; LANGE, L.: Feminist Interpretations of Jean-Jacques Rousseau. Penn State Press, 2010.

26 ROUSSEAU, J. J.: Du Contract Social. 1793, online, s. 203. 
viazané na formu vlády a ktoré by ju nepomáhali chránit. ${ }^{27}$ Práve tento princíp slúžil ako argument pre odmietanie Voltairovho návrhu založit' v Ženeve, kde obaja filozofi pôsobili, divadlo. ${ }^{28}$ Takáto novinka by zničila rozširujúcu sa siet' dobrovol’ných združení, známych aj ako 'kruhy', ktorých členovia sa združovali práve v časoch divadelných predstavení. Tieto spoločnosti významne prispeli $\mathrm{k}$, ,zdôrazneniu zdravého rozumu a úsudku" a ochrane republikánskych hodnôt medzi občanmi. ${ }^{29}$ Napriek tomu, že Rousseau nikdy neopísal tieto spolky ako strany, či frakcie, boli v skutočnosti politickými organizáciami ženevskej strednej triedy. Od roku 1730 sa ich pozornost' vo zvýšenej miere upriamila na politiku, a to z dôvodu eskalujúceho konfliktu medzi strednou triedou a aristokraciou, ktorý pretrvával počas celého 18. storočia. V šest'desiatych rokoch 18. storočia a potom opätovne, na začiatku rokov osemdesiatych, zohrali dôležitú úlohu pri konfliktných stretoch Reprezentantov, ako sa nazývali stúpenci strednej triedy a aristokratickou triedou strany Patríciov. Líder Reprezentantov považoval za nutné zabezpečit' si súhlas 'kruhov' predtým, ako uzavrel dohodu so svojimi aristokratickými oponentmi. Tí považovali 'kruhy' za centrá rozvracačov štátneho zriadenia, ktoré sa v roku $1782 \mathrm{v}$ tzv. Pacifikácii podarilo potlačit. ${ }^{30}$

Vo svojom Dopise d'Alembertovi z roku 1758 Rousseau vyjadril k týmto združeniam svoj najvyšší obdiv a zdôraznil ich hodnotu vo zvyšujúcom sa občianskom povedomí a zabezpečení dobrej vlády. ${ }^{31}$ Obával sa, že by ich potlačenie mohlo viest' ku dehonestácii občianstva, oslabeniu postavenia jedinca, či strate podpory pre vládu. Jeho argumenty jasne indikujú jeho podporu dobrovol’ným združeniam, spoločnostiam občanov, ktoré podl'a jeho názoru zásadne prispievajú $\mathrm{k}$ dobrej funkcii zodpovednej vlády. ${ }^{32}$

Väčší prelom v chápaní koncepcie občianskej spoločnosti v jej dnešnom zmysle priniesla druhá polovica 18. storočia. Myslitelia škótskeho osvietenstva, ovplyvnení vo vel'kej miere Aristotelom a stoickou filozofiou, Adam Ferguson, David Hume a Adam Smith boli jedni z prvých, ktorí začali na občiansku spoločnost' poukazovat' ako na siet' medzil'udských vzt'ahov oddelených od štátu. Zdôrazňovali pritom význam kapitalizmu ako základ pre nový individualizmus, ako aj význam spoločnosti, ktorá sa bude môct' odvolávat' na určité práva. Jedným z najrozsiahlejších diel týkajúcich sa občianskej spoločnosti tohto obdobia bola Esej o histórii občianskej spoločnosti od Adama Fergusona z roku 1767. Ferguson sa v knihe pokúsil vzkriesit' ideály a občianske cnosti z čias Rímskej ríše a implementovat’ ich do spoločnosti, kde pomaly kapitalizmus striedal obdobie feudalizmu. Aby bolo vôbec možné mat' nejakú formu občianskej spoločnosti, muži, nie ženy samozrejme v tomto období, musia začat' preukazovat' aktívny záujem o dianie v politickom zriadení, v ktorom žijú namiesto toho, aby sa snažili len o zarobenie peňazí a potom sa od komunity odklonili.

Takto stanovená téza má pre súčasné chápanie pojmu občianskej spoločnosti stále silnú relevanciu. Nocionálne je teda možné už v tomto období vidiet’ určitú demarkáciu pojmu, ktorá sa $\mathrm{v}$ značnej miere dá prirovnat' $\mathrm{k}$ jeho súčasným definíciám. Na-

27 ROUSSEAU, J. J.: Du Contract Social. 1793, online

28 GOLDSHMIDT, M. L.: Rousseau on intermediate associations. Transaction Publishers, 2007, s.124.

29 ROUSSEAU, J. J. - BLOOM, A.: Politics and the Arts. Cornell University, 1968, s. 98.

30 GOLDSHMIDT, M. L.: Rousseau on intermediate associations. Transaction Publishers, 2007, s. 125.

31 ROUSSEAU, J. J. - BLOOM, A.: Politics and the Arts. Cornell University, 1968, s.105.

32 PENNOCK, J. R. - CHAPMAN, J. W.: Voluntary Associations. Transaction Publishers, 2007. 
priek tomu však tak, ako pre autorov 17. storočia, aj pre Fergusona a jeho súčasníkov stál takto postavený nový koncept cnostnej participácie na verejnom živote na strane jednej, no na strane druhej videli despotizmus, nekultúrnost' a zastaraný spôsob verejného života. ${ }^{33}$ Ked'že Ferguson odmietal teóriu Spoločenskej zmluvy, prezentoval civilnú spoločnost' ako tú, ktorá prešla pomalým procesom rozvoja a zdokonalovania v umení, obchode, ako aj vo vojenskej kultúre. Považoval ju za rozvinutú a obnovenú spoločnost', kde sú občianske slobody chránené vládou a kde bola dosiahnutá určitá úroveň ekonomického, politického a najmä sociálneho rozvoja. Občiansku (civilnú) spoločnost' teda videl aj ako protiklad barbarského národa a veril, že prostredníctvom vládnej politiky, postupného vzdelávania a vytvárania si nových návykov je možné barbarský národ/ despotickú spoločnost' pretransformovat' na spoločnost' občiansku. ${ }^{34}$ Jedným z relevantných odkazov pre súčasný kontext však zostáva dôležitost' a dôraz, ktorý Ferguson kládol na politickú zodpovednost' zahŕňajúcu aktívny prístup k verejnému životu a k hodnotám viazaným na občiansku participáciu a občianske cnosti.

Adam Smith vo vel'kej miere súhlasil s názormi Adama Fergusona, že zásadným princípom občianskej spoločnosti je vlastná individuálna morálka, ktorá sa zakladá na verejnom uznaní rovesníkov, ktorých spája spoločné morálne cítenie. ${ }^{35}$ Smith zdôrazňoval, že l'udia majú prirodzenú túžbu a potrebu zlepšovat' svoje životné podmienky. Táto túžba postupne naberá formu 'zvyšovania majetku'. Na to, aby túto túžbu naplnili, by jednotlivci mali požívat' slobodu rozhodnút' sa, ako naložia s prostriedkami, schopnost’ami a zručnost’ami, ktoré im boli nadelené. Vláda tu mala jedine tri úlohy: ochranu pred vonkajším nepriatel’om, udržiavanie chodu verejných prác a služieb vrátane vzdelávacieho systému a nakoniec exaktnú správu justície. Smith uvádzal občiansku spoločnost' ako spoločnost' ekonomickú - oddelenú, ale na druhej strany chránenú štátom, v ktorej sa mediátorom stáva verejný poriadok založený na súkromnom vlastníctve, zmluvách a vol’nom pohybe pracovných síl. ${ }^{36} \mathrm{~V}$ Smithovom pohl'ade, liberálna komerčná spoločnost' vyžaduje, ale hlavne podporuje občianske cnosti. Videl ju nie len ako určité útočisko od ekonomickej sféry, ale aj ako zdroj ekonomických schopností. Občianska spoločnost' sa vynára v reakcii na celospoločenské zmeny, na zmenu v pracovnom trhu, v del'be práce (ekonomické zmeny); zavedenie určitých právnych a justičných štandardov (politické a právne inovácie), kultúrnosti a zvýšenia nárokov na morálku, slušnost' a rozmanitý súbor l'udských atribútov ako je družnost', vl'údnost', l'udskost' a sebakontrola (morálna revolúcia). ${ }^{37}$

Diela Adama Smitha a Adama Fergusona boli preložené do d'alších jazykov a šírili sa po celej Európe. Vel'ký ohlas zaznamenali v Nemecku a tak sa dostali aj do rúk Imanuela Kanta a Fridricha Hegla. ${ }^{38}$

33 ANHEIER, H. K. - KALDOR, M. - GLASIUS, M.: Global Civil Society. Oxford: Oxford University press, 2001.

34 PIETRZYK-REEVES, D.: Adam Ferguson's Republicanism. In: Politeja,2008, s.67-83

35 SMITH, A.: Theory of Moral Sentiment. Oxford, Clarendon Press, 1976.

36 SMITH, A.: Theory of Moral Sentiment. Oxford, Clarendon Press, 1976, s.36.

37 BOYD, R.: Adam Smith on civility and civil society. Oxford university press 2013, s. 443-463

38 OZ-SALZBERGER, F.: An Essay on the History of Civil Society. Cambridge University Press, 1995, s. 322. 
Občianska spoločnost' Immanuela Kanta je navrhnutá tak, aby v nej každý človek mohol prostredníctvom právneho systému dosiahnut' slobodu. Je založená na existencii zákonov, vytvorená a udržiavaná na základe ústavy tak, aby boli zabezpečené práva a slobody všetkých občanov štátu. Jednotlivci si zaistujú svoje základné práva aj tým, že akceptujú autoritu štátu. $\mathrm{V}$ tomto prípade sa Kant prikláňa $\mathrm{k}$ Lockovmu vnímaniu štátneho aparátu, ktorý je postavený na trojdelení moci tak, aby sa ani jedna zo zložiek výkonnej, zákonodarnej, či súdnej moci nemohla stat' natol'ko silnou, aby bola schopná ohrozovat' slobodu ako primárne právo každého občana. Občania tvoria občiansku spoločnost' práve z dôvodu zabezpečenia a zaistenia svojich práv. Ako opak takéhoto zriadenia vidí Kant Hobbsovu naturálnu podstatu l'udskej bytosti, v ktorej sa vynárajú nie tie najlepšie l’udské vlastnosti a pudy, a v ktorej prevláda stav násilia a vojny 'všetkých proti všetkým'. Sociálna organizácia vo forme občianskej spoločnosti napomáha k udržaniu poriadku, morálky, či k sebakontrole, ktorá síce vychádza zo strachu z represívnych opatrení, no poskytuje jednotlivcom istotu pokojného a slobodného žitia v komunite. Občianska spoločnost' je potrebná aj preto, že v rámci svojho zriadenia poskytuje striktné pravidlá vo forme zákonov, ktoré regulujú život každého jednotlivca tak, že jeho sebecká podstata nezasahuje do všeobecných požiadaviek na udržanie občianskeho poriadku. Je to spôsob života, pri ktorom je vyžadovaný individuálny rešpekt voči slobode ostatných. ${ }^{39}$

Immanuel Kant vo svojich úvahách o 'dobrom žití' pokračuje d'alej a ako prvý z učencov svojej doby posúva hranice občianskej spoločnosti za hranice národného štátu. Vo svojom diele Idea of a universal history on a cosmo-political plan z roku 1784 predkladá devät’ návrhov, na základe ktorých sa snaží preukázat' svoje tvrdenie, že racionálna a morálna svojprávnost' nevyhnutne časom potlačí túžbu po egocentrickom individualizme. Vo svojej piatej propozícii uvádza, že „najväčšim problémom l'udského druhu, do riešenia ktorého ho núti príroda, je dosiahnutie univerzálnej občianskej spoločnosti, ktorá sa bude zakladat' na impériu politickej spravodlivos$t i{ }^{\text {“ }}{ }^{40}$ Univerzálnu občiansku spoločnost' tiež povyšuje na vzor budúceho pokojného a mierového usporiadania sveta, kde sa môžu naplno rozvinút' l'udské vlohy a kde môže byt' naplno využitý l'udský potenciál. Štáty si budú vedomé svojho ohrozenia a vojnám sa budú vyhýbat', pričom sa postupne začnú pripravovat' na vznik vel'kého nadštátneho telesa. Hovorí, že ,po viacerých prevratných revolúciách sa raz dosiahne najvy̌šsi úmysel prírody, univerzálny svetoobčiansky stav ako lono, v ktorom sa rozvinú všetky pôvodné vlohy l'udského druhu“". ${ }^{41}$ Immanuel Kant sa vo svojom ponímaní občianskej spoločnosti neviaže na spoločnost' $v$ rámci národného štátu, no ako jediný filozof danej doby ju zasadzuje do kontextu globálneho.

Tu je možné spomenút', že pokial' hovoríme o vzniku konceptu globálnej občianskej spoločnosti, relatívne mladého konceptu, ktorý je v súčasnosti rozpracovávaný akademikmi, či vedcami vo vzt’ahu k medzinárodnej politike, globalizácii alebo iným témam a často tvorí samostatnú oblast' vedeckého výskumu, tento výskum má svoj východzí bod práve pri uvedenej piatej propozícii Immanuela Kanta o univerzálnej občianskej spoločnosti.

39 DeLUE, S.M - DALE, T.: Political Thinking, Political Theory, and Civil Society, Routledge, 2015, s. 400.

40 KANT, I.: Idea of a universal history on a cosmo-political plan. 1824, s.387.

41 KANT, I.: Idea of a universal history on a cosmo-political plan. 1824, s. 391. 
Kým ešte klasickí myslitelia zdôrazňovali jednoliatu identitu štátu a spoločnosti, $\mathrm{v}$ dobre raného novoveku sa tieto dva subjekty začali definitívne vnímat' ako samostatné entity. Bolo to obdobie tvorby štátnej byrokracie a ustanovenia rôznych štátnych inštitúcií - centrálnych bánk, profesionálnej armády, vzdelávacieho systému - všetko jasne oddelené od súkromných záujmov panovníka. Georg Friedrich Hegel, popredný myslitel' romantizmu videl l'udské potreby, uspokojenie l’udského záujmu, či súkromné vlastníctvo ako determinujúce súčasti občianskej spoločnosti. Považoval ju za 'systém potrieb', v ktorom jednotlivci zosúladili svoje osobitné súkromné záujmy s požiadavkami a očakávaniami spoločnosti. ${ }^{42}$ Jednotlivci nachádzajú životné uspokojenie vo vzt’ahu $\mathrm{s}$ inými slobodnými jednotlivcami, ktorí nie sú rodinnými príslušníkmi, ale skôr nezávislými osobami ${ }^{43}$ Hegel tvrdil, že je občianska spoločnost' vhodným usporiadaním na vytvorenie a udržiavanie rovnováhy v širokej škále l’udských potrieb a záujmov, ale je to primárne štát ako najvyššia forma etického života, ktorý do systému l'udských potrieb vkladá istý poriadok tým, že zabezpečuje stabilitu súkromného vlastníctva, sociálneho zaradenia, či del'by práce. Dobre fungujúca občianska spoločnost' nemôže existovat' bez usmernení zo strany štátu.

Heglove moderné chápanie občianskej spoločnosti úplne zmenilo doterajší význam tohto konceptu. Kým pre Immanuela Kanta boli výrazy 'bürgerliche Gesellschaft' ${ }^{\prime 4}$ a 'Staat' synonymami, pre Hegla sa stali antonymami. ${ }^{45}$ Termín 'bürgerliche Gesellschaft' používal na označenie občianskej spoločnosti vyslovene ako 'civilnej spoločnosti', teda sféry ekonomického a sociálneho zriadenia regulovaného občianskym zákonníkom, nie priamo závislej na vlastnom politickom usporiadaní štátu. ${ }^{46} \mathrm{Na}$ rozdiel od predchádzajúceho dyadického modelu štát/ spoločnost', vypracoval Hegel schému triadickú, v ktorej sa občianska spoločnost' ako sprostredkovatel' etiky nachádza medzi makro-komunitou štátneho aparátu a mikro-komunitou rodiny. ${ }^{47}$ Ked’že bola kategória štátu a rodiny jasne definovaná, Hegelova občianska spoločnost' zahŕňala prakticky všetko okrem týchto dvoch oblastí. V Hegelovej teórii bol koncept občianskej spoločnosti určený ako objekt historického vývoja a vnímaný ako sféra konfliktných záujmov mimo sféry štátu. Snažil sa opísat' súbor podmienok, na základe ktorých môže moderný človek žit' harmonickým životom, slobodným životom. Pre Locka, Fergusona alebo Kanta bol tento harmonický život dosiahnutel'ný v rámci života v občianskej spoločnosti. Pre Hegla však skutočný, 'etický život' bolo možné dosiahnut' len v rámci štátu. Všetky elementy l'udského bytia nachádzajú svoje miesto a zmysel len vo vzt’ahu voči štátu, a tak sa pre Hegla stáva štát ontologickou prioritou. ${ }^{48}$

42 MARX, K.: Towards a Critique of Hegel's Philosophy of Rights: Introduction. In: McLELLAN, D. Selected writings. Oxford: Oxford university Press, 1977.

43 PELED, Y.: Rousseau's Inhibited Radicalism: An Analysis of His Political Thought in Light of His Economic Ideas. In: American Political Science Review, 1980, vol. 74, n. 4, s. 1034-1045.

44 Nemecký výraz: buržoázna spoločnost'

45 ZALESKI, P.: Tocqueville on Civilian Society: A Romantic Vision of the Dichotomic Structure of Social Reality. In: Archiv Für Begriffsgeschichte, vol. 50, 2008, s. 264.

46 HONDERICH T.: The Oxford Companion to Philosophy. Oxford: Oxford University Press, 2005.

47 BOBBIO, N.: Democracy and Dictatorship: The Nature and Limits of State Power. University of Minnesota Press, 1989

48 OLDFIELD, A.: Hegel: Rational Freedom in the ethical Community. Routledge, 1990, s. 208. 
Myšlienky Friedricha Hegla prešli neskôr určitou dichotómiou. Na jednej strane smerom doprava viedli k liberálnemu rozdeleniu medzi politickú spoločnost’ a spoločnost' občiansku, ktorá zahŕňa všetky neštátne aspekty spoločnosti vrátane kultúry, sociálnych vecí a politiky. ${ }^{49}$ Takto postavenú teóriu d’alej rozpracovával Alexis de Tocqueville ${ }^{50}$, ktorý vo všeobecnosti nasledoval Heglovu percepciu sociálnej reality, kde možno oddelit' spoločnost' politickú a občiansku. Na rozdiel od Hegla však tvrdil, že systém politických a občianskych združení musí tvorit' akúsi protiváhu tak liberálnemu individualizmu, ako aj postupnej centralizácii štátu. V súlade s jeho liberálnym stanoviskom, efektivita aktivít $\mathrm{v}$ občianskej spoločnosti ako 'nezávislého oka spoločnosti' záleží aj na jej organizačnej forme. ${ }^{51} \mathrm{~V}$ svojej štúdii o demokracii v Amerike, de Tocqueville tvrdí, že garancie individuálnych slobôd je možné nájst' v tom, čo nazýva 'demokratické zložky'; tieto zahŕňajú miestnu samosprávu, odlúčenie cirkvi od štátu, slobodu tlače, nepriame vol'by, nezávislé súdnictvo a predovšetkým, život v spoločenstvách. Bol hlboko ohromený množstvom asociácií v občianskom živote l'udí v Amerike, na základe čoho argumentuje, že aktívne združenia občanov sú podmienkou pre život $\mathrm{v}$ slobode a rovnosti. Ked’že štát preberá stále viac a viac funkcii každodenného života, ked’že sa del'ba práce stala komplexnejšou a ked’že sa požiadavky na prerozdelenie bohatstva neustále zvyšujú, aktívny dobrovol’nícky, občiansky sektor je nutný na uplatňovanie kontroly voči štátnej moci. ${ }^{52}$

Na strane druhej možno sledovat' vývoj Heglových myšlienok a teórií aj smerom dol'ava. Reprezentantom tohto smeru v kontexte skúmania historických koreňov konceptu občianskej spoločnosti sa stal Karl Marx, ktorý označil občiansku spoločnost' za ekonomickú základňu ako kontrast voči 'superštruktúre' spoločnosti politickej, teda štátu. ${ }^{53}$ Ako bolo spomenuté, na označenie občianskej spoločnosti Hegel používal termín, 'bürgerliche Gesellschaft'. Marx však termín poňal doslovne a občianska spoločnost' nebola pre neho ničím iným ako spoločnost'ou buržoáznou, ktorá v realite slúžila jedine obhajobe a dosahovaniu konkrétnych záujmov buržoáznej triedy ${ }^{54}$ Odmietol pozitívnu rolu štátu, ktorú proklamoval Hegel, ked’že veril, že sa pod vplyvom kapitalizmu štát správa ako represívny aparát, ako nástroj triednej dominancie. ${ }^{55}$ Napriek tomu s Heglom súhlasil v tom, že o občianskej spoločnosti možno hovorit' v zmysle

49 ZALESKI, P.: Tocqueville on Civilian Society: A Romantic Vision of the Dichotomic Structure of Social Reality. In: Archiv Für Begriffsgeschichte, vol. 50, 2008.

50 Alexis de Tocqueville vo svojom diele Demokracia v Amerike z roku 1835 neuvádza priamo pojem 'občianska spoločnost'. V kapitole VII. hovorí o politických asociáciách, združeniach, ktoré sú „ustanovované na podporu verejného poriadku, obchodu, priemyslu, morálky a náboženstva“, no sú vytvárané na základe jednotnej vôle občanov - jednotlivcov a aktívnych politikov na výkon kontroly voči moci, ktorá vládne. (Tocqueville, 1835, s. 185-93)

51 TOCQUEVILLE, A.: de Democracy in America. G. Adlard, Harvard, 1839.

52 ANHEIER, H.K. - KALDOR, M. - GLASIUS, M.: Global Civil Society. Oxford University press, 2001, s. 3-22.

53 MARX, K.: Towards a Critique of Hegel's Philosophy of Rights: Introduction. Oxford university Press, 1977.

54 RICHTER. M.: Montesquieu and the Concept of Civil Society. In: The European Legacy.1998, S. $33-41$.

55 BOBBIO, N.: Democracy and Dictatorship: The Nature and Limits of State Power. University of Minnesota Press, 1989. 
skutočného konania, občianskeho aktivizmu a zapájania sa do vecí verejných. Pomenované aktivity však považoval za tak masívne ovplyvňované triednym antagonizmom a protichodnými záujmami, že vo svojej podstate nemôžu byt' ani len všeobecne prínosné. ${ }^{56}$ Tvrdil, že v buržoáznej spoločnosti ludia pristupujú jeden $\mathrm{k}$ druhému ako $\mathrm{k}$ prostriedku na dosahovanie vlastných ciel'ov a v rámci takéhoto konania sa l'udia odcudzujú tak od vlastného l'udského potenciálu, ako aj jeden od druhého navzájom. ${ }^{57}$ Buržoázny štát Marx nazýva 'iluzórnou formou života'. L'udstvo teda v modernom svete môže existovat' len pokial' sa spoločnost' 'rozloží' a sformuje do jednej konkrétnej triedy - proletariátu. ${ }^{58} \mathrm{Na}$ rozdiel od Hegla, Marxova doktrína predpokladá, že sa štát, ktorý je nástrojom triednej nadvlády, stratí spolu s rozložením jeho jednotlivých tried. Kým pre Hegla mala občianska spoločnost' viest' k univerzálnej etickej entite štátu, pre Marxa vedie k budúcej negácii existujúceho rozdielu medzi občianskou spoločnost'ou a štátom a k budúcej jednote l’udstva. Jeho teória bola zameraná na charakterizovanie tejto jednoty ako skutočnej slobody, ktorá nefunguje prostredníctvom štátu, ktorý jednotlivcov od seba izoloval a odcudzoval, ale jednoty, ktorú je možné dosiahnut' prostredníctvom reunifikácie politickej a občianskej spoločnosti. ${ }^{59}$

Pre súčasné moderné poňatie konceptu občianskej spoločnosti je nutné spomenút' d'alšieho významného myslitel'a zo začiatku 20. storočia, Antonia Gramsci. Gramsci bol členom talianskeho parlamentu a generálnym sekretárom tajnej frakcie Komunistickej strany Talianska, ked' bol v roku 1926 zadržaný režimom Benita Mussoliniho a väznený po dobu desiatich rokov. Vo svojom diele Listy z väzenia, ktoré tvorí zväzok viac ako tridsiatich listov, napísaných počas obdobia stráveného vo fašistickom väzení, diskutuje aj koncept občianskej spoločnosti, spoločnosti politickej a štátu. ${ }^{60}$ Vo svojej interpretácii sa vracia od Marxa k Heglovi, ktorý videl občiansku spoločnost' ako súbor všetkých rôznych druhov a foriem sociálnej interakcie. Gramsci vo svojej teórii zachádza d'alej a úplne oddel'uje pojem občianska spoločnost' od interakcií ekonomických. Na rozdiel od Marxa a Hegla ju umiestňuje dovnútra štátu ako jeho neoddelitel'nú súčast', ako potenciálne miesto vzniku ideologickej moci. Zatial', čo je v Marxových spisoch občianska spoločnost' zobrazovaná ako priestor pre individuálny egoizmus, Gramsci ju opisuje ako priestor pre jednotlivca a organizácie s potenciálom pre racionálnu reguláciu a slobodu. Zatial', čo je spoločnost' politická nástrojom sily, spoločnost' občianska je nástrojom súhlasu a konsenzu. Ide o sféru vzniku a činnosti ideologického aparátu, ktorého úlohou je získat' a vykonávat' autoritu, prostredníctvom ktorej je potom tento konsenzus možné dosahovat ${ }^{61}$ Občianska spoločnost' sa, podl'a neho, skladá z kultúrnych inštitúcií, najmä z cirkvi, ale tiež škôl,

56 BROWN, B. R.: Marx and the Foundations of the Critical Theory of Morality and Ethics. 2001, s. 74.

57 ANHEIER, H.K. - KALDOR, M. - GLASIUS, M.: Global Civil Society. Oxford University press, 2001, s. 12.

58 MARX, K.: Towards a Critique of Hegel's Philosophy of Rights. Oxford university Press, 1977.

59 PIETRZYK-REEVES, D.: Civil Society - Conceptual History from Hobbes to Marx. [online]. [2016-02-12] 2001. Dostupné na internete: <https://www.academia.edu/7868984/Civil_ Society_Conceptual_History_from_Hobbes_to_Marx>

60 GRAMSCI, A.: Selections from Prison Notebooks of Antonio Gramsci. International Publishers, 1971, s. 483.

61 BOBBIO, N.: Democracy and Dictatorship: The Nature and Limits of State Power. University of Minnesota Press, 1989. 
združení a asociácií, odborových organizácií a iných inštitúcií mimo inštitúcie štátneho aparátu. Je potrebné prízvukovat', že svoju víziu občianskej spoločnosti Gramsci vsadil do arény sociálnych interakcii mimo štát a mimo trh. Prezentoval ju ako plne vyvinutý autonómny systém, ktorý je schopný odolávat' ekonomickým krízam a chránit’ štát. ${ }^{62}$

Ako poznamenáva Fleming (2000), Gramsciho práca doviedla analytikov 20. storočia $\mathrm{k}$ usporiadaniu troch zásadných komponentov nápomocných $\mathrm{k}$ porozumeniu konceptu občianskej spoločnosti. Po prvé, občianska spoločnost' mala byt' ponímaná v zmysle širšom ako len obyčajný 'nositel' zavedených postupov a presvedčení; formovala totiž siet' sociálnych diskusii a kontroverzii, v ktorých sa vytvárali rôzne aliancie, kolektívne identity, etické hodnoty, normy orientované na konkrétne opatrenia v praxi. Po druhé, dynamická, kreatívna stránka občianskej spoločnosti bola zdôraznená vytvorením neformálnych sietí, iniciatív a sociálnych hnutí, ktoré presahujú rámec formálnych združení. Po tretie, občianska spoločnost' začala byt' vnímaná ako 'verejná sféra', nenásilná aréna diskusií a vzájomného vzdelávania sa, oddelená od štátu a hospodárstva, kde sa l'udia spájajú, aby vytvárali spoločný diskurz, verejnost', ktorá núti štát na vlastnú legitimizáciu pred verejnou mienkou.

Historicky prvé pokusy o definíciu konceptu občianskej spoločnosti sa odvolávali na vytvorený politický systém. Termín bol používaný nie ako protiklad k štátnemu zriadeniu, ale ako protiklad k prirodzenému stavu ludstva, teda k naturálnemu stavu. Neskôr bol vnímaný ako synonymum k štátu, štátnemu zriadeniu. Jednou z hlavných tém, o ktoré sa filozofi 18. storočia zaujímali bola vízia autonómneho spoločenského poriadku, vzt’ah medzi jednotlivcom, spoločnost’ou a štátom, medzi tým, čo je verejné a tým, čo patrí do sféry súkromného. Koncept občianskej spoločnosti znamenal, aspoň pre niektorých z nich, riešenie daného problému. Pre Fergusona, Smitha či Immanuela Kanta bol tento koncept normatívnou kategóriou, ktorá popisuje želaný stav spoločenského poriadku, nie striktne oddeleného od štátu. Bola to aréna jednoty a spájania občanov, aréna solidarity, morálky, spoločne vyznávaných cností a hodnôt, ale aj aréna aktívneho občianstva, zodpovednosti voči verejnému poriadku a aktívnej participácie na verejnom živote. Na začiatku 19. storočia hovoríme o špecifickom ekonomickom zriadení, kde sa rozlišuje sféra rodiny, občianskej spoločnosti a sféra štátu (Hegel), kde je štát chápaný ako jednoznačne oddelená, najvyššia a najefektívnejšia forma sociálneho života. Napriek tomu však, že Hegel a neskôr jeho nasledovník, Karl Marx, evidovali občiansku spoločnost' ako samostatný objekt výskumu, v ich ponímaní sa sama rozplynula na jednej strane do univerzálneho štátu (Hegel), na strane druhej bola občianska spoločnost' znovu zjednotená so spoločnost'ou politickou (Marx).

Napriek tomu, že sa v priebehu dejín obsah termínu občianska spoločnost' menil, všetky definície mali spoločného menovatel’a. Bola ním spoločnost' založená na pravidlách, na poriadku, ktorý vznikol ako výsledok konsenzu medzi jednotlivcami. Meniace sa definície občianskej spoločnosti len reflektovali rôzne spôsoby, ktorým sa tento konsenzus v rôznych obdobiach dejín dosahoval. Vyjadrovali tiež diferentné skutočnosti, ktorým sa v rôznych obdobiach dejín prikladal kvantitatívne meniaci sa akcent. Už od počiatku moderných dejín sa jednou z hlavných sociálno-politických

62 GRAMSCI, A.: Selections from Prison Notebooks of Antonio Gramsci. International Publishers, 1971. 
tém stali občianske práva, práva a slobody jednotlivcov. Občianska spoločnost' bola spoločnost’ou založenou na pravidlách, na slobodách, spoločnost'ou, kde zákony vystriedali silu a donútenie, či svojvol'né pozbavenie slobody. V 19. storočí sa témou stali politické práva a aktívni účastníci spoločnosti občianskej boli na chvíl'u považovaní za vychádzajúcu buržoáziu . V 20. storočí to bolo zas robotnícke hnutie ako opozit voči vládnej moci a témou sa stala sociálna a ekonomická emancipácia. ${ }^{63}$ Takto sa postupne termín občianskej spoločnosti menil a okresával, jeho význam sa zužoval na pomenovanie čoraz konkrétnejšieho sociálno-politického fenoménu. Niektorí súčasní myslitelia, filozofi, či akademici vidia ideu občianskej spoločnosti ako normatívny, ideálny model sociálneho života alebo novú, prípadne obnovenú paradigmu pre politickú vedu. V každom prípade je to však len jeden z d’alších náhl’adov.

Uvedená analýza historickej genézy tohto konceptu poskytuje perspektívu, na základe ktorej je možné deklarovat', že globálna občianska spoločnost' má svoje filozofické a historické korene pevne ukotvené. Jav, ktorý predpokladá združovanie sa občanov s ciel'om ovplyvňovat' veci verejného záujmu nie je novým javom. V tej najširšej perspektíve ide skutočne o združovanie sa l'udí a prejavy ich spoločnej vôle vplývat' na rozhodovacie procesy týkajúce sa správy verejných vecí. V užšej podobe môžeme hovorit' aj o perspektívach, na základe ktorých je možné skúmat', kvalifikovat' a kategorizovat' moderné teórie občianskej spoločnosti a globálnej občianskej spoločnosti vo vzt’ahu k politickým teóriám a teóriám medzinárodných vzt’ahov.

\section{Obnova konceptu občianskej spoločnosti a korene vzniku globálnej občianskej spoločnosti}

Skutočné obnovenie konceptu občianskej spoločnosti prebiehalo v 80. rokoch 20. storočia spolu so spoločenskými a politickými zmenami v regiónoch Latinskej Ameriky a strednej a východnej Európy. Pôvodne existovala polemika o tom, ktorý z dvoch regiónov ako prvý koncept občianskej spoločnosti znovu použil, no podl'a všetkých dostupných informácií išlo o simultánne prebiehajúci jav tak v strednej a východnej Európe, ako aj v Latinskej Amerike. V oboch prípadoch sa termín občianska spoločnost' preukázal ako užitočná koncepcia $\mathrm{v}$ boji proti militarizovaným režimom. S ohl'adom na regionálny aspekt a obmedzenost' priestoru pre obsiahnutie problematiky budeme pozornost' sústredit' na skutočnosti, ktoré prispeli k obnove konceptu občianskej spoločnosti a dodali globálny rozmer v oblasti strednej/východnej Európy.

Jedným z prvých, ktorí identifikovali tento koncept ako úzko súvisiaci s rétorikou opozičných skupín bola skupina tzv. disidentov, intelektuálov odmietajúcich prispôsobit' sa požiadavkám systému $\mathrm{v}$ uvedených krajinách európskeho kontinentu. Občianska spoločnost' pre nich znamenala víziu niečoho nesmierne pozitívneho. Vo svojom unikátnom kontexte bola znovuzrodeným pojmom, ktorý mal v očiach disidentov viac normatívny ako empirický charakter. Opozícia sa spočiatku proti komunistickému režimu prejavovala len vo forme akejsi túžby po 'revízii', po socialistickom presvedčení o možnosti humanizácie a čiastočnej demokratizácie zvnútra. ${ }^{64}$

63 KALDOR, M.: The Idea of Global Civil Society. 2003, s. 583-593.

64 MICHNIK, A.: Letters from Prison and Other Essay. University of California Press,1986, s. 371. 
Avšak brutálne potlačenie nepokojov v Mad'arsku a Pol'sku v roku 1956, či neskôr invázia vojsk Varšavskej zmluvy do bývalého Československa v roku 1968 definitívne podlomili akékol'vek nádeje o reformovatel'nosti tohto systému. Stratégiou opozície sa preto stalo „využitie inherentných rozporov v systéme ${ }^{\text {“ }}{ }^{65} \mathrm{~s}$ ciel'om rozširovania priestoru pre nezávislé, autonómne aktivity občanov.

Diskurz o občianskej spoločnosti vyjadroval ciele opozície nie len zo strategického hl'adiska, ale aj z hl'adiska princípov, na základe ktorých bola táto stratégia postavená. Kým množstvo princípov a postojov nepochybne vychádzalo z reakcie voči politickému režimu, taktiež boli postavené na filozofii a hodnotách, ktoré boli disidentom blízke. Ako uvádza Tucker vo svojej knihe The Philosophy and Politics of Czech Dissidence from Patočka to Havel (2000), filozofia Jána Patočku, či Václava Havla bola odvodená z tradícií fenomenológie, kde boli vyzdvihované individuálne vedomie, sloboda myslenia a presvedčenia, či l'udská intuícia. Stavali sa voči neslobode, predsudkom, klamstvám. Havlovo notoricky známe poňatie 'disidentstva' ako 'žitia v pravde ${ }^{\prime 66}$ na rozdiel od 'žitia v klamstve' vyjadrovalo princípy l'udskej dôstojnosti, integrity a morálky, ktoré sa stali centrálnymi piliermi občianskej spoločnosti v strednej a východnej Európe. ${ }^{67}$

Väčšina zložiek filozofie nesúhlasu či disidentstva môže byt' videná v myšlienke o 'antipolitike', mad’arského spisovatel'a a filozofa György Konráda (1984), ktorá odkazovala na úplné odmietnutie snáh o dosiahnutie moci zo strany opozície. 'Antipolitika' poskytovala určitý protipól voči politizácii každodenného života v komunizme. Tá nakoniec viedla $\mathrm{k}$ rozsiahlej nedôvere voči politike a taktiež $\mathrm{k}$ zisteniu, že na to, aby boli aktivity občianskej spoločnosti efektívne, musí spoločnost' fungovat' v rámci hraníc, ktoré jej existujúci systém nastavuje radšej, ako sa snažit' tento systém uzurpovat'. ${ }^{68}$

Skutočnost', že tu občianska spoločnost' stála na princípe antipolitiky a nepredstavovala explicitnú hrozbu štátu indikuje, že zmeny, ktoré napokon podlomili režim pochádzali nie zo sféry politiky, ale zo sféry l’udského uvedomenia; $;{ }^{69}$ z existenciálnej revolúcie. ${ }^{70}$ Tým, že disidenti odsúdili dovtedajšie tradičné formy politiky, ich myšlienky a názory v podstate pripravili pôdu pre vznik nového typu vládnutia, ktoré bolo postavené na verejnej občianskej participácii v rôznych oblastiach spoločenského žitia. Ako uvádza Ost ,antipolitika nie je negáciou politiky, ale relokáciou zosobnenia politickej verejnosti zo štátu do spoločnosti““. ${ }^{71}$ Disidenti 80. rokov 20. storočia oživili pojem aktívneho občianstva a ul'ahčili postupný rozvoj toho, čo sa následne vyformovalo do podoby známej ako 'občianska spoločnost': autonómnych združení, ktoré popierali dusivý konformizmus a presadzovali toleranciu, individualitu, slobodu a pluralizmus.

Globálny aspekt obnovenému konceptu občianskej spoločnosti v strednej a vý-

65 KOLAKOWSKI, L.: Hope and Hopelessness. 1971, s. 42.

66 HAVEL, V.: The Power of the Powerless: Citizens Against the State in Central-Eastern Europe. 1985, s. 40.

67 Ibid

68 KONRÁD, G.: Antipolitics: An Essay. Henry Holt, 1987. 243 s.

69 MICHNIK, A.: Letters from Prison and Other Essay. University of California Press, 1986, s. 371.

70 HAVEL, V.: The Power of the Powerless: Citizens Against the State in Central-Eastern Europe. 1985, s. 40.

71 OST, D. Solidarity and the Politics of Anti-Politics: Opposition and Reform in Poland Since 1968. Temple University Press, 1990, s. 16. 
chodnej Európe priniesol vzostup globálnych interpersonálnych prepojení jednotlivých aktivistov. Podpisom Záverečného aktu Konferencie o bezpečnosti a spolupráci v Európe z roku 1975 v Helsinkách sa Sovietsky Zväz zaviazal tak k rešpektovaniu zásad medzinárodného práva, ako aj $\mathrm{k}$ rešpektovaniu l'udských práv a základných slobôd vrátane slobody myslenia, svedomia, náboženského vyznania a viery. ${ }^{72}$ Práve podpis tejto medzinárodnej zmluvy predstavoval právny základ, na ktorom bolo možné predostriet' a realizovat' d'alšie opozičné ciele a rozširovat' obsah autonómnych občianskych aktivít. Naviac, helsinský efekt $\mathrm{v}$ kombinácii s rýchlym technologickým vývojom komunikačných prostriedkov, boli rozhodujúcimi faktormi, ktoré ovplyvnili vytvorenie väzieb medzi východoeurópskymi disidentmi a západoeurópskymi mierovými hnutiami a l’udskoprávnymi organizáciami, a tak umožnili vytvorenie priestoru pre občiansku spoločnost'. ${ }^{73}$ Tieto väzby demonštrujú vzájomné vzt’ahy medzi občianskou spoločnost'ou, štátom a medzinárodným systémom.

V očiach medzinárodnej komunity bola občianska spoločnost' strednej a východnej Európy reprezentovaná dvomi zásadnými hnutiami: a to neformálnou československou občianskou iniciatívou Charta $77^{74}$ a pol'ským odborovým hnutím Solidarita, ${ }^{75}$ čím ich aktivity nadobúdali skutočne globálny rozmer.

Činnost' Charty 77 bola finančne a personálne podporovaná založením Medzinárodného výboru na podporu Charty 77 v Československu, ktorý vznikol v Paríži ešte v roku 1977 z iniciatívy bývalého šéfredaktora časopisu Esprit, bývalého komunistického ministra, člena Socialistickej strany a Pierra Emmanuela, ktorý

72 Bod 1 (b) VII. Záverečného aktu Konferencie o bezpečnosti a spolupráci v Európe. Dostupné na internete: http://www.osce.org/mc/39501?download=true

73 KALDOR, M.: Global Civil Society: An Answer to War. Cambridge: Polity. 2003, s. 189.

74 Charta 77 bola neformálnou občianskou iniciatívou rokov 1977 až 1992 postavená okolo dokumentu, Charta 77 (Prohlášení Charty 77) z 1. januára roku 1977, ktorý kritizoval nedodržiavanie záväzkov vyplývajúcich z podpisu Záverečného aktu Konferencie o bezpečnosti a spolupráci v Európe, ako aj zmlúv OSN a československej Ústavy vtedajším komunistickým režimom. Charta vydala celkom 572 dokumentov, v ktorých nabádala najmä na rešpektovanie l'udských práv a slobôd.

75 Solidarita vznikla v roku 1980 ako nezávislé samosprávne odborové hnutie odštiepené od taktiež známej pol'skej odborovej organizácie Výbor ochrany robotníkov (KOR z roku 1976 - Komitet Obrony Robotników od roku 1978 Komitet Samoobrony Społecznej KOR, KSSKOR). Do jari 1981 vstúpilo do Solidarity viac ako milión Poliakov, čím sa jej vplyv významne zvýšil. V rámci hnutia bolo vypracovaných niekol'ko ekonomických a politických požiadaviek, taktiež právne postavených na medzinárodných dohodách a zmluvách, ktoré sa Sovietsky zväz zaviazal rešpektovat'. Členovia pracovali tajne, vydávali tlač, rozširovali letáky, organizovali pomoc pre l’udí prenasledovaných komunistickým režimom. Podl'a dostupných zdrojov bolo hnutie masívne finančne podporované zo strany Vatikánu, nakol'ko bol za vtedajšiu hlavu katolíckej cirkvi v októbri roku 1978 zvolený pol'ský občan, Karol Wojtyla. Ďalším nie menej významným spojencom boli Spojené štáty americké pod vedením prezidenta Ronalda Reagana. Zdroje aj priamo na internetovej stránke americkej Ústrednej spravodajskej služby (Central Intelligence Agency) uvádzajú podrobný rozpis, akými spôsobmi tu zasahovala americká CIA, ktorá prostredníctvom svojich agentov priamo podporovala aktivity tohto pol'ského hnutia. Aj vd’aka obrovským finančným tokom zo zahraničia nadobudla Solidarita masovú spoločenskú podporu a spolu s KOR je považovaná za jeden z dominantných vplyvov, ktoré prispeli k pádu komunizmu. 
výboru predsedal. Ten bol d’alej široko podporovaný francúzskymi intelektuálmi a osobnostami verejného života. ${ }^{76}$ Okrem Výboru sa do podpory a rozširovania činnosti exulantov zapojilo niekol'ko d'alších francúzskych organizácií, napríklad Comité des intellectuels pour l'Europe des libertés (CIEL), založená roku 1978 Raymondom Aronom a Alainom Ravennom, Assocation Jan Hus, či Výbor pre slobodné a socialistické Česko-Slovensko. Vel'mi významnou v podpore aktivít česko-slovenských disidentov, či signatárov Charty 77 sa stala aj Jan Hus Educational Foundation (JHEF), založená v máji 1980 skupinou britských filozofov na Oxfordskej univerzite. Fond slúžil okrem iného aj na finančné dotácie akademickej, literárnej, umeleckej a vedeckej činnosti jednotlivcov, ktorým táto činnost' v Československu nebola slobodne umožnená. Nakol'ko boli možnosti podporného financovania zo strany Britov limitované a americké daňové zákony komplikovali alokovanie finančných prostriedkov do charít mimo USA, boli d'alej založené Jan Hus Educational and Cultural Fund (USA) a Jan Hus Fund/Fonds Jan Hus (Kanada) ako sesterské organizácie britskej JHEF. ${ }^{77}$ Jednou z nosných organizácii na podporu činnosti členov Charty 77 bola Nadácia Charty 77 založená v roku 1978 v Štokholme, českým disidentom a jadrovým fyzikom, Františkom Janouchom. Nadácia akumulovala prostriedky a spravovala štipendiá, ktoré následne prerozdel'ovala nezávislým skupinám, prípadne jednotlivcom, ktorých nadácia považovala za vhodných adeptov na finančnú podporu. Každá organizácia bola viazaná na vzájomnú spoluprácu, všetky navzájom rešpektovali svoje jedinečné misie, či už na poli podpory akademických či kultúrnych aktivít disidentov, exulantov a iných osôb, ktorých práva a slobody boli porušované komunistickým režimom alebo vo forme prerozdel'ovania finančných prostriedkov za účelom podpory činnosti, ktorá bola týmto režimom zakazovaná.

Týmto spôsobom sa postupne v 80. rokoch 20. storočia formovala siet' aktivít občianskej spoločnosti, ktoré nadobúdajú medzinárodný charakter a ktoré je možné v súčasnosti označit', a ktoré aj mnohými v súčasnosti označené je, ako počiatok vzniku skutočnej globálnej občianskej spoločnosti v modernom zmysle.

\section{Občianska spoločnost'/ globálna občianska spoločnost' - súčasné ponímanie konceptu, teoretické vymedzenie a definície}

Ako bolo úvodom poznamenané, unifikovaná, uzavretá a všeobecne akceptovaná definícia občianskej spoločnosti/globálnej občianskej spoločnosti neexistuje. Ako bolo stručne uvedené na začiatku, $\mathrm{k}$ danej tematike neexistuje ani len unifikovaný, uzavretý a všeobecne akceptovaný pojmový aparát. Globálna občianska spoločnost' je neustále meniacou sa veličinou, živou, nie jasne uchopitel’nou entitou, ktorú aj výstupy akademických výskumov kategorizujú s vel'kou opatrnost'ou a s akcentom na subjektívne vnímanie konkrétneho skúmaného javu. Napriek tomu však snahy o ich nocionálne vymedzenie pretrvávajú. Nasledujúcu podkapitolu bude spočiatku tvorit' súhrnný konspekt súčasných prelínajúcich sa výskumov občianskej spoločnosti a globálnej občianskej spoločnosti a ich definící tak, ako ich prezentujú jednotliví dominantní akademici a výskumní pracovníci v odbore.

76 GUTMANN, B.: Relais et réseaux de la Charte 77 en France, entre 1977 et 1989. 2011, s.50.

77 DAY, B.: The Velvet Philosophers. A\&C Black, 1999, s. 344. 
Je tiež dôležité spomenút', že v rámci nasledujúceho exkurzu operujeme najmä s výskumami, ktoré sú mladšie ako 20 rokov, t.j. od roku 2001. Tým sa zabezpečí čo možno najväčšia aktuálnost' a reliabilita. V d’alšej časti podkapitoly sa pokúsime o vlastnú rámcovú definíciu konceptu, ktorá bude analyticky derivovaná a) z uvedeného historického diskurzu o genéze občianskej spoločnosti, b) z integrálneho fenoménu globalizácie a c) zo súčasne prebiehajúcich výskumov o implikácii vplyvov občianskej spoločnosti na medzinárodne rezonujúce problematiky.

\subsection{Súčasné výskumy a percepcie konceptu občianskej spoločnosti/globálnej občianskej spoločnosti}

Medzi dominantné školy, ktoré za posledných 20 rokov ovplyvnili výskumy konceptu globálnej/ občianskej spoločnosti patrí jednoznačne britská London School of Economics (d’alej aj ako „LSE“). Renomovaní akademici ako Mary Kaldor, Meghnad Desai, John Keane, Helmut Anheier, Abdullahi AnNa'im, Ulrich Beck alebo Richard Falk od roku 2001 každoročne vydávajú niekol'konásobne celosvetovo ocenenú publikáciu Global Civil Society Yearbook ako súhrn výskumov, dát, myšlienok, výstupov konferencií, debát, kampaní a aktivít aktérov globálnej občianskej spoločnosti. Táto skupina akademikov od počiatku zdôrazňovala, že koncept je neurčitý a sporný, no v roku 2001 skoncipovali empirickú pracovnú definíciu, s ktorou po nasledujúce roky niektorí z nich operovali. ${ }^{78}$ Išlo o ,„sféru idei, hodnôt, inštitúcií, organizácií, sietí a jednotlivcov alokovaných medzi rodinou, štátom a trhom a ktorých činnost'zasahuje za hranice národných spoločností, politík a hospodárstiev/ ekonomík ${ }^{\prime 79}{ }^{79}$ Prácu tohto tímu l'udí je možné označit' za jeden z najsúhrnnejších, najdetailnejších a najprehl'adnejších výskumných súborov diel, ktoré možno v dostupnej literatúre $\mathrm{k}$ téme vidiet'.

Po detailnom preskúmaní prác jednotlivých autorov, či už z LSE alebo iných inštitútov a škôl je však možné vidiet' rozkoly v ponímaní skúmaného konceptu a to $\mathrm{v}$ dvoch základných líniách. Tak, ako bolo možné historicky počas niekol'kých storočí vnímat' diskusiu o tom, či občianska spoločnost' je alebo nie je súčast'ou či synonymom štátu, v 21. storočí je odpoved' na túto otázku jasná a zhodujú sa na nej takmer všetci: občianska spoločnost' je sférou mimo štátneho aparátu. Posledné roky tu však prebiehajú iné diskusie, ktoré rozdel'ujú autorov a ich vnímanie a definície občianskej a globálnej občianskej spoločnosti do niekol'kých kategóríi. Prvou otázkou v užšom zmysle je, či by do diskurzu o občianskej spoločnosti mali byt' zahrnuté obchodné spoločnosti/ ekonomické inštitúcie. V širšom zmysle tu hovoríme o zahrnutí trhového hospodárstva, či ekonomiky všeobecne, teda či je alebo nie je občianska spoločnost' súčastou trhu. ${ }^{80}$

Je zrejmé, že prvá línia autorov inšpirovaná filozofiou Antonia Gramsciho, nezamýšl’a do svojich definícii zahrnút' trh, trhové hospodárstvo či trhovú ekonomiku,

78 ANHEIER, H. K. - KALDOR, M. - GLASIUS, M.: Global Civil Society. Oxford University press, 2001.

79 ANHEIER, H. K. - KALDOR, M. - GLASIUS, M.: Global Civil Society. Oxford University press, 2001, s. 17.

80 KUMAR, K.: Global Civil Society. In: European Journal of Sociology / Archives Européennes De Sociologie / Europäisches Archiv Für Soziologie, vol. 48, no. 3, 2007, s. 413-434. 
pričom je pre nich občianska spoločnost' entitou nachádzajúcou sa mimo ekonomickú sféru. Medzi nich je možné zaradit Jeana Cohena, Andrewa Arata a Jeffreyho Alexandera. ${ }^{81}$ Taktiež je možné predpokladat', že boli ich názory silne podporené myšlienkami Jürgena Habermasa, ktorý v roku 1996 napísal, že „to, čo je dnes mienené pojmom 'občianska spoločnost' je v rozpore s pojmom uživaným v čase marxistickej éry a už nezahŕña hospodárstvo ako bolo konštituované súkromným právom a zavádzané prostredníctvom trhov ku práci, kapitálu a komoditám. Jej inštitucionálne jadro skôr zahŕña tie nevládne a neekonomické prepojenia a dobrovolné združenia, ktoré upevňujú komunikačné štruktúry verejnej sféry v spoločnosti. "82 Jean Cohen a Andrew Arato vo svojej knihe Občianska spoločnost' a politická teória (1992) tvrdia, že: „Súčasný diskurz o občianskej spoločnosti sa zameriava na novú, konkrétne ne-triedne zameranú formu kolektivnej činnosti, orientovanú a napojenú na zákonné, združovacie a verejné inštitúcie spoločnosti. Tieto musia byt diferencované nie len od štátu, ale aj od kapitalistickej trhovej ekonomiky. " ${ }^{83}$ Napriek tomu, že sa jedná o citácie z kníh vydaných v 90. rokoch 20. storočia, o diela Jürgena Habermasa, či Cohen a Arata sa opiera d’alšia vlna výskumníkov, teda ide o fenomén priamo zasahujúci aj do diskurzu prebiehajúceho po roku 2001. Do skupiny, ktorá občiansku spoločnost' nevidí ako podmnožinu prelínajúcu sa s kategóriou ekonomických vzt'ahov patrí aj čast' akademikov z LSE, definitívne sem možno zaradit' Helmuta Anheiera, ktorý v roku 2005 jasne uvádza: „termin občianska spoločnost'sa vzt'ahuje na súbor inštitúcií, organizácii a aktivit situovaných pomedzi štát, svet obchodu a rodinu. Konkrétne to zahŕñ dobrovolné, neziskové organizácie rôznych druhov, filantropické inštitúcie, sociálne a politické hnutia, formy sociálnej participácie a zainteresovanosti, verejnú sféru a hodnoty a kultúrne vzory, ktoré sa nimi spájajü“". ${ }^{84}$

Na strane druhej však možno pozorovat' kritiku týchto názorov a prúd teoretikov, ktorí sem zahŕňajú aj oblast', kde sú jednotlivci vol’ne zapojení do manufaktúr, trhov a vzájomnej výmeny služieb, v rámci ktorej je stále vhodné označenie 'občianska' (sféra), nakol'ko sú tieto aktivity generované vo verejnom diskurze. Východiskom tu možno označit' myšlienky Adama Smitha, či neskôr Karla Marxa, ktorí identifikovali občiansku spoločnost' primárne cez ekonomické vzt’ahy v rámci trhu. Čiastočne sem možno zaradit' aj Immanuela Kanta. Pre Marxa bola definujúcou esenciou občianskej spoločnosti práve ekonomika vo svojej vol'ne plynúcej forme, oddelená od štátu a iných komunálnych inštitúcií. Pre Kanta, ako aj d’alších myslitel'ov skorej modernej

81 COHEN, J. - ARATO, A.: Civil Society and Political Theory. Cambridge, MA: MIT Press, 1992. Kritikou konceptu občianskej spoločnosti sa detailnejšie zaoberá HAMILTON, L.: 'Civil Society': Critique and Alternative." Global Civil Society and Its Limits. Houndmills, Basingstoke: Palgrave Macmillan, 2003.s. 63-81. Tiež, ALEXANDER, J.C.: The Civil Sphere. Oxford and New York: Oxford University Press, 2006.s. 23-36. a tiež ALEXANDER, J.C.: "Introduction." Real Civil Societies. London and Thousand Oaks, CA, 1998. s. 1-19. KEANE, J.: Global Civil Society? Cambridge: Cambridge University Press, 2003. s. 77-87.

82 HABERMAS, J.: Civil Society and the Political Public Sphere. In: Between Facts and Norms: Contributions to a Discourse Theory of Law and Democracy. MIT Press, 1996, s.329.

83 COHEN, J. - ARATO, A.: Civil Society and Political Theory. Cambridge, MA: MIT Press, 1992, s. 2.

84 ANHEIER, H.K.: A Dictionary of Civil Society, Philanthropy and the Third Sector London: Routledge, 2005, 320 s. stat' 5. 
doby bolo jedným z hlavných ingrediencií v živote občianskej spoločnosti, orientovanej tak národne, ako aj globálne to, čo Montesquieu nazval 'le doux commerce', ${ }^{85}$ ktorý zjemňuje a cibrí barbarské spôsoby ${ }^{86}$ Obchod nielenže odporuje vojne, stimuluje tiež kvalitu dôvery, zodpovednosti a reciprocity, všetky životodarné kvality pre prosperujúcu občiansku spoločnost'. ${ }^{87}$

Medzi autorov, ktorí nasledujú a opierajú sa o vyššie uvedené myšlienky je možné zaradit' Victora Peréz - Diaza, ktorý tých, ktorí neoddelitel'ne zarad'ujú koncept občianskej spoločnosti nielen do oblasti trhu, ale celej siete liberálnych politických inštitúcií nazýva 'generalistami'. Občianska spoločnost' je podl'a neho „ideálny typ vzt'ahujúci sa na súbor politických a sociálnych inštitúcií, ktoré sú charakterizované limitovanou, zodpovednou vládou striktne podliehajúcou právnemu poriadku štátu, volnému a otvorenému trhu, pluralitou dobrovolných organizácií a sfére slobodnej verejnej diskusie“ “ ${ }^{88}$ Ďalším autorom zaoberajúcim sa aj charakterizovaním pojmu občianska spoločnost' je Ernest Geller, ktorý sa vo svojich dielach postupne prepracováva rôznymi konceptualizáciami, pričom ekonomický faktor tu vždy zohráva jednu zo zásadných úloh. Občianska spoločnost' podl'a neho nie je len súborom mimovládnych inštitúcií, ktoré majú schopnost' pôsobit' proti štátnej moci. Je to historický a sociologický fenomén, ktorý vyžaduje detailnú vzájomnú súhru niekol'kých predpokladov: moderne nastavených spoločenských podmienok, politickú autonómiu podporenú stabilným, ale pružným štátnym aparátom, regulovanú ekonomickú slobodu, absenciu náboženských monopolov a flexibilný, zmluvný charakter sociálnych vzt’ahov ${ }^{89}$ Tak Perés- Diaz, ako aj Ernest Geller vnímajú občiansku spoločnost' ako ideálnu, typicky liberálnu komerčnú spoločnost’ so všetkými jej prejavmi. Viac vyhraneným 'generalistom' je austrálsky profesor John Keane, ktorý ponúka svoju širokú definíciu, tentokrát už priamo globálnej občianskej spoločnosti, kde nekompromisne zahŕn̆a ekonomické faktory: „Je dynamickým mimo-vládnym systémom navzájom prepojených socio-ekonomických inštitúcií, ktoré pokrývajú celú Zem a ktorý má komplexné účinky, ktoré sú cítit' vo všetkých jej štyroch rohoch. Globálna občianska spoločnost' nie je statickým objektom, ani 'fait accompli'. Je neukončeným projektom, ktorý pozostáva z niekedy husto, niekedy natenko utkanej siete, pyramíd a zhlukov socio-ekonomických inštitúcii a aktérov, ktorí sa organizujú cezhranične s rozvážne premysleným ciel'om vykreslenia celého sveta novými spôsobmi. Tieto mimovládne inštitúcie a aktéri majú tendenciu pluralizovat' moc a problematizovat násilie; následne je ich mierotvorné alebo občianske účinky cítit' všade...na samotnej planetárnej úrovni “. ${ }^{90}$ Do takto komplexnej biosféry Keane zahŕňa 'ohromujúcu rôznorodost' interagujúcich druhov': organizácií, občianskych a obchodných iniciatív, koalícií, spo-

$85 \mathrm{Z}$ francúzštiny: 'sladký obchod'.

86 KUMAR, K.: Global Civil Society. In: European Journal of Sociology / Archives Européennes De Sociologie / Europäisches Archiv Für Soziologie, vol. 48, no. 3, 2007, s. 413-434.

87 KANT, I.- REISS, H. - NISBET, H.B.: Perpetual Peace: A Philosophical Sketch. In: KANT, I. 1991. Political Writings. Cambridge Texts in the History of Political Thought . Cambridge: Cambridge University Press, 1991, s. 114.

88 PERÉZ - DIAZ, V.: The Return of Civil Society. The Emergence of Democratic Spain.Harvard University press, 1998, s. 220.

89 GELLER, E.: Conditions of Liberty: Civil Society and Its Rivals. Hamish Hamilton, 1994, s. 54.

90 KEANE, J.: Global Civil Society?.Cambridge University Press, 2003, s. 35-36. 
ločenských hnutí, lingvistických komunít a kultúrnych identít, z ktorých majú všetky minimálne jednu vec spoločnú: „naprieč nesmiernym geografickým vzdialenostiam a napriek prekážkam v čase sa ciel'avedome organizujú a vedú svoje cezhraničné aktivity, obchody a politiky mimo hraníc vládnych štruktúr s minimom násilia a maximom rešpektu pre princípy a zásady civilizovanej moci, ktorá sa zdiel'a v rámci rôznych spôsobov života. " 91

Ďalším zaujímavým rozporom v ohraničení a definovaní globálnej/ občianskej spoločnosti je otázka, či v sebe tento pojem zahŕňa aj spoločnost' politickú alebo naopak, či je pojem politická spoločnost' širší ako spoločnost' občianska. Taktiež vychádzajúc z historických diskurzov, túto tému ako jeden z prvých otvoril Alexis de Toquiville, pričom na rozdiel od Johna Locka, pre ktorého bola politická a civilná spoločnost' synonymom, sám rozoznával rozdiel medzi uvedenými subjektmi. Spoločnost' politickú definoval ako súbor aktivít populácie, ktorá sa aktívne zaoberá záležitostami vlády a moci. V jeho prístupe bola politická spoločnost' oddelená od občianskej, ktorá naopak obsiahla privátne vzt’ahy medzi občanmi a ich nespočetnými nepolitickými asociáciami. ${ }^{92} \mathrm{~V}$ podobnom duchu sa niesla aj filozofia Antonia Gramsciho. ${ }^{93} \mathrm{Z}$ nej vychádza mnoho súčasných odborných článkov, ktoré oddel'ujú tieto dve entity, ${ }^{94}$ no konsenzus o tom, ktorá čo poníma a aký je konkrétny obsah týchto pojmov je aj v najbližšej dobe nepravdepodobný. ${ }^{95}$

Diskurz o tom, či sú ekonomické inštitúcie, obchodné spoločnosti a všeobecne trh v celej svojej komplexnosti l'udských zdrojov súčast'ou občianskej spoločnosti nie je samozrejme téma tejto práce. Taktiež nie je témou, či v sebe politická spoločnost' nosí spoločnost' občiansku alebo či je práve tá pôdou pre vznik spoločnosti politickej. Táto diskusia a po nej iné, d’alšie, ktoré by bolo možné uviest' má však potenciál prezentovat', akým spôsobom sa dajú posúvat' a akým spôsobom sa stále, v súčasnosti, posúvajú mantinely definície občianskej spoločnosti a následne aj jej globálnej verzie. Aj prostredníctvom vyššie uvedeného bolo ciel’om poukázat' na tú skutočnost', že napriek značnej odbornej nejednotnosti v teoretickej definícií konceptu má tento

91 KEANE, J.: Global Civil Society?.Cambridge University Press, 2003, s. 35-36.

92 HANN, CH. - DUNN, E.. ed. Civil Society: Challenging Western Models. Routledge, 1996, s. 256.

93 FOLEY, M W. - EDWARDS, B: The Paradox of Civil Society In Journal of Democracy. 1996, s. $38-52$.

94 CHATTERJEE, P.: Lineages of political society: Studies in postcolonial democracy. Columbia University Press rozoberá vznik politickej a občianskej spoločnosti v Indii; CRANE, E.: Civil society vs. Political society: China at a crossroads. Washington DC: The Cato institute, pre ktorého je občianska spoločnost' sféra dobrovol'ných, súkromných interakcii, kým politická spoločnost' je sférou vládnych mandátov a autorít. MONAT, J. -BEAUPAIN, T. : The role of economic and social councils in social dialogue. In: M. Gold (Ed.), New frontiers of democratic participation at work (s.73-99). Hampshire: Ashgate pojednávajú o snahách inštitucionalizovat' postavenie politickej spoločnosti. ARATO A. - COHEN, J.L.: Civil Society and Political Theory.MIT Press hovoria o úlohe politickej spoločnosti ako o úlohe sprostredkovatel'a medzi spoločnost'ou občianskou a štátom., pričom spoločnost' politická je podla nich hlboko zakorenená v spoločnosti občianskej (Cohen - Arato 1994, str. X).EDWARDS, M.: Civil society. Polity 2009. s. 25 etc.

95 ANHEIER, H.K.: A Dictionary of Civil Society, Philanthropy and the Third Sector. Routledge, 2005, s. 320 . 
potenciál vyvolávat' stále živé diskusie a to práve z dôvodu, že viac ako teoretickým konceptom, je globálna/ občianska spoločnost' predovšetkým entita empirická, funkčná, praktická, neustávajúca, aktívna a stále sa dynamicky vyvíjajúca. Fakt, že sa tento koncept a diskusia o ňom šíri vo vyššej kvantite a kvalite stále d’alej naznačuje, že aj jeho dôležitost' exponenciálne rastie.

\subsection{Globalizácia a percepcie globálnej občianskej spoločnosti}

Vel'mi jednoduchý, logický a jasný nexus medzi občianskou spoločnost'ou a globálnou občianskou spoločnost'ou urobila jedna z vedúcich predstavitel'ov LSE, Profesorka Mary Kaldorová. ${ }^{96}$ Tvrdí, že napriek tomu, že má termín 'občianska spoločnost' dlhú evolúciu a jeho súčasný význam vychádza aj z jeho historického poňatia, kontext, $\mathrm{v}$ ktorom dnes figuruje, sa zásadne líši od toho minulého. Jednoducho povedané, to, čo je dnes nové na koncepte 'občianskej spoločnosti' je globalizácia. Občianska spoločnost' už viac nie je pripútaná $\mathrm{k}$ hraniciam teritoriálneho štátu. ${ }^{97}$

Globalizáciou možno rozumiet' proces neustáleho zvyšovania vzájomnej prepojenosti medzi spoločnost’ami tak, že udalosti dejúce sa na určitom teritóriu majú stále väčší vplyv na spoločnosti a l’udí na inom, viac či menej vzdialenom teritóriu. ${ }^{98}$ Globalizovaný svet je ten, ktorého politické, sociálne, kultúrne a ekonomické deje sa stávajú navzájom prepojené, ovplyvňované, často navzájom závislé, či dokonca kauzálne. Tieto deje možno všeobecne rozdelit do troch skupín: sociálne, ekonomické a politické, pričom masový rozvoj informačných technológii a komunikačných prostriedkov v každej z nich masívne akceleroval rozsah globalizačného vplyvu. Internet, celosvetové televízne a rádiové vysielanie, telekomunikačné služby, globálne printové, či iné médiá a 'revolúcia' v ich rozvoji ultimatívne ovplyvnili dosah nielen občianskej spoločnosti na globálne témy.

Po detailnom výskume je možné uviest' pät' verzií konceptu globálnej občianskej spoločnosti podobne, ako ich sumarizuje a prezentuje Mary Kaldorová. Prvé dve z nich sú derivované z klasickej alebo tradičnej verzie myšlienok o občianskej spoločnosti, d’alšie tri sa vzt’ahujú na súčasnejšie perspektívy, ktoré skloňujú výraz globálna občianska spoločnost' novými spôsobmi.

'Societas civilis' je najstaršou verziou a hovorí o tvorbe štátu, ktorého základom je stabilný právny poriadok, civilizovanost' a spoločnost', ktorá zakazuje, či redukuje násilie v l'udských vzt'ahoch v rámci hraníc vlastného štátu. Ciel'om 'societas civilis' je bezpečná, nenásilná spoločnost'. Predpokladom je, že takáto 'societas civilis' potrebuje štát s verejným monopolom na legitimizáciu donucovacích prostriedkov. $\mathrm{Na}$ základe takejto tézy teda občianska spoločnost' od štátu byt' oddelená nemôže, naopak, oddel'uje sa len od spoločností necivilizovaných a vojny. Za nedostatok je tu možné považovat' neexistenciu kosmopolitného poriadku alebo akéhosi svetového štátu, ktorý by uvedený monopol dokázal garantovat' a aplikovat' globálne. Predzvest’ou globálnej vlády, či globálnej governmentality je vytvorenie súboru medzinárodného

96 KALDOR, M.: Global Civil Society: An Answer to War. Cambridge: Polity. 2003, s. 189.

97 KALDOR, M.: Global Civil Society: An Answer to War. Cambridge: Polity. 2003, s. 189.

98 BAYLIS, J. - SMITH, S. - OWENS, P.: The Globalization of World Politics. Oxford University Press, 2011, s. 636. 
humanitárneho práva, medzinárodného súboru l’udských práv a slobôd, ustanovenie Medzinárodného trestného tribunálu, expanzia medzinárodných mierových síl, ktorých ideu opísal aj Immanuel Kant ako univerzálnu občiansku spoločnost' v zmysle kosmopolitného právneho poriadku, ktorý je garantovaný medzinárodným právom, zmluvami a inštitúciami. ${ }^{99}$ Absencia prepracovanejšej siete globálnych inštitúcií, prípadne jedného 'svetového štátu' môže byt' znakom nekompletnosti a nie vždy efektívnej činnosti globálnej občianskej spoločnosti.

'Buržoázna spoločnost' (Bürgerliche Gesellschaft)' je identifikovaná s komerčnou víziou občianskej spoločnosti elaborovanou myslitel'mi škótskeho osvietenstva ako Adamom Smithom a Adamom Fergusonom, ktorí tvrdili, že vznik komerčnej/ trhovej spoločnosti so sebou priniesol aj vznik takých jedincov, ktorí sú nevyhnutnou podmienkou existencie občianskej spoločnosti. Ciel'om tejto spoločnosti je vzostup trhovej spoločnosti ako podmienky pre garanciu osobnej slobody a pre rovnováhu medzi štátom a trhom. V súčasnosti je sem možné zaradit' už spomínaných vedcov, Johna Keana a Ernesta Gellera. „Prenesené do globálneho úrovni, občianska spoločnost'môže byt' viac alebo menej prirovnávaná ku 'globalizácii zdola' - ku všetkým tým aspektom globálneho rozvoja vo vnútri a pomimo štátu a medzinárodných politických inštitúcií vrátane transnacionálnych korporácií, migrácie zahraničných investícií, globálnej kultúry etc. “100

'Aktivistická verzia' je akýmsi nástupcom disidentských hnutí v strednej a východnej Európe 80. rokov 20. storočia. V tejto perspektíve je možné sa odvolat' na aktívny prístup k občianstvu, rastúcu občiansku samoreguláciu a organizáciu mimo formálnych politických kruhov, prostredníctvom ktorých je následne možné vyvolávat' politický tlak, či už na úrovni národnej alebo globálnej. Ciel’om je získanie vplyvu, samotné ovplyvnenie vecí verejných, ideálne vecí globálnych. Národná, regionálna, náboženská alebo iná identita nie je zásadná, pre aktivistov je zdiel’aný kozmopolitizmus dôležitejší. Znovu, prenesené do globálnej úrovne, zameranie je tu na Habermasovu verejnú sféru 'transnacionálnej siete aktérov na presadzovanie konkrétnych záujmov', akými sú organizácie typu Greenpeace alebo Amnesty International, globálne sociálne hnutia, revolučné hnutia, organizácie ludsko-právnych alebo environmentálnych aktivistov, či teoretikov.

'Neoliberálna verzia' zas môže byt' vnímaná ako nástupca verzie 'buržoáznej spoločnosti' aktualizovaná a modernizovaná tak, aby reflektovala súčasné formy kapitalistickej globalizácie. Týka sa rozšírenia vol'ného obchodu a minimálne regulovaného trhu ako najlepšieho spôsobu podpory činnosti občianskej spoločnosti, ktorá je tu ponímaná ako sféra súkromných/mimovládnych iniciatív a aktivít. Ciel'om je tu rozšírenie 'západných' liberálnych hodnôt, ich osobitná globalizácia. V zmysle tejto definície pozostáva občianska spoločnost' zo života $v$ asociáciách a združeniach - v neziskovom, dobrovol'nom, tret’om sektore, ktorý sa snaží nielen o obmedzenie štátnej moci, ale taktiež o poskytnutie určitého zastúpenia funkcií, ktoré má primárne plnit’ šát najmä v oblasti zdravotníctva a sociálneho systému. Túto definíciu je možné asi najjednoduchšie preniest' na globálnu úroveň, pričom asociácie a združenia

99 KANT, I.: Idea For A Universal History With A Cosmopolitan Purpose.1824. Cambridge University Press. 1991, s. 41-53.

100 KALDOR, M.: Global Civil Society: An Answer to War. Cambridge: Polity. 2003, s. 15. 
poskytujú istý politický a sociálny protipól voči procesu globalizácie chápanej ako ekonomická globalizácia, liberalizácia, deregulácia a vzrastajúca mobilita kapitálu a tovaru. Pri absencii 'svetového štátu' zoskupenia mimovládnych organizácii vykonávajú funkcie potrebné na zmiernenie dopadov ekonomickej globalizácie. ${ }^{101}$ Takáto neoliberálna vízia je spájaná aj s „koncom dejín“ teoretikov, akým je Francis Fukuyama a iných, ktorí vidia vzrastajúcu globálnu občiansku spoločnost' (homogenizáciu ludstva) cez prizmu svetového triumfu liberálneho kapitalizmu.

Poslednou je 'postmoderná verzia' globálnej občianskej spoločnosti. Zhodne s postmodernou filozofiou zdôrazňuje pluralitu, rôznorodost', ale aj toleranciu. Postmoderné náhl'ady so svojím dôrazom na prelom tradičných atribútov novodobej súčasnosti môžu voči konceptu globálnej občianskej spoločnosti pôsobit' nepriatel'sky. Napriek tomu je však pre mnoho postmoderných teoretikov, ako napríklad Zygmunta Baumana globalizácia akcelerátor postmoderných tendencií. Aktuálna masívna migrácia l'udí, vzájomné prelínanie sa jednotlivých kultúr, destabilizácia národných štátov a iné následky modernej doby vytvárajú svet poznačený, okrem iného, aj snahou o všeobecné pochopenie, prípadne akceptáciou rozdielov. Napriek existencii obrovských, multikultúrnych rozdielov, ktoré častokrát vedú na jednej strane $\mathrm{k}$ fanatickým sporom a vzniku vel'mi extrémne naladených fundamentalistických skupín, na druhej strane sa tu vynára aj spoločná globálna kultúra podporovaná medzinárodným turizmom, cestovaním a komunikáciou. V postmodernom pohl'ade môže človek hovorit' o pluralite globálnych občianskych spoločností prostredníctvom rôznych globálne organizovaných skupín. Sem možno zaradit’ tak náboženské skupiny so širokým vplyvom ako islam, či krest'anstvo v ich rôznych frakciách, ako aj širokú škálu športových organizácií, prípadne siete ludsko-právnych organizácií. Každá má svoju vlastnú charakteristiku, dáva dôraz inému javu a skutočnostiam a spory, či konflikty medzi nimi a vo vnútri nich sú neoddelitelnou súčast'ou ich existencie. Všetky sú však víziou globálnosti a globálnej občianskej spoločnosti. Postmodernisti zdôrazňujú dôležitost' rôznych identít, národných, náboženských, kultúrnych, ako aj početnost' takto rozličných identít ako podmienku globálnej občianskej spoločnosti. ${ }^{102}$

Ciel'om uvedenej podkapitoly bolo na jednej strane prezentovat', $v$ ako široko nastavenom spektre je možné s konceptom globálnej občianskej spoločnosti pracovat'. Na druhej strane tiež bolo s pomocou uvedeného výskumu ciel'om určit' ten najvhodnejší náhl'ad na d’alšiu, hlbšiu analýzu problematiky tejto práce. $\mathrm{V}$ rámci transformácie z občianskej spoločnosti do jej globálnych podôb je nutné určit' a pomenovat' niekol'ko faktorov/ menovatel'ov, ktoré neskôr pomôžu zúžit' optiku náhl'adu na skúmaný jav. Pokial' je skúmaným javom vplyv, ktorý dokáže vyvinút' globálna občianska spoločnost' na medzinárodnú mierovú politiku, bolo by nedôvodné pracovat' napríklad s postmoderným náhl'adom na globálnu občiansku spoločnost', nakol'ko ten nezachytáva komplexne tie faktory, ktoré sú práve pre túto tému zásadné. $\mathrm{V}$ postmoderne ide aj o zdôraznenie

101 V zmysle ustálenej definície podl’a Únie medzinárodných asociácii je mimovládnou organizáciou právne konštituovaná organizácia tvorená súkromnými osobami alebo organizáciami bez účasti alebo reprezentácie akejkol'vek vlády. Termín vznikol na pôde OSN a obyčajne sa vzt'ahuje na organizácie nekonvenčného ziskovo orientovaného charakteru. Môžu existovat’ na lokálnej, regionálnej, ale aj medzinárodnej úrovni.

102 KALDOR, M.: Global Civil Society: An Answer to War. Cambridge: Polity. 2003, s.16. 
identity, rôznorodost', o konflikt a zmierenie, toleranciu, variabilitu a mnohé iné, ktoré síce sú normatívne aplikovatel'né, no funkčne a empiricky s témou nesúvisia priamo. Taktiež, neoliberálna verzia, ktorá síce poníma občiansku spoločnost’ ako súbor asociácií, združení, čo by bolo kompatibilné s d’alším výskumom, ale menovatelom sú tu ekonomické procesy, ktoré opakovane s témou práce nesúvisia priamo.

\subsection{Globálna občianska spoločnost’ - charakteristické znaky, definícia, vplyv}

Optika, cez ktorú d’alej nazeráme na funkcionalitu globálnej občianskej spoločnosti sa bude najviac približovat' aktivistickej verzii skúmaného konceptu. Tak, ako nás aj analýza genézy samotnej občianskej spoločnosti priviedla k udalostiam konca 80. rokov 20. storočia vo východnej a strednej Európe, aktivistická perspektíva je najbližšie k verzii konceptu globálnej občianskej spoločnosti, ktorá sa vyvinula práve z udalostí v tomto regióne. Aktivistická optika je o politickej emancipácii. Je o splnomocnení jednotlivcov a rozširujúcej sa, silnejúcej demokracii, aktívnej občianskej participácii a autonómii. Jej menovatel’om je existencia globálnej verejnej sféry - globálneho priestoru, kde komunikácia neprebieha inštrumentálnou formou, kde existuje siet' transnacionálnych aktérov, globálnych sociálnych hnutí s rôznym zameraním: ludsko-právnym, environmentálnym, humanitárnym etc. Zásadným elementom je tu prítomnost' medzinárodných médií, prostredníctvom ktorých sa kampane aktérov dostávajú do pozornosti čo najširšieho spektra prijímatel’ov a stávajú sa globálnymi. Ciel'om je presadzovanie konkrétnych záujmov a ovplyvnenie konkrétnych skutočnosti v rámci globálnej verenej sféry. ${ }^{103}$

\section{Charakteristické znaky}

Globálna občianska spoločnost' v tomto kontexte teda zahŕňa občianske aktivity, ktoré: (1) majú záber na globálne rezonujúce témy, (2) vyžadujú cezhraničnú komunikáciu, (3) majú globálnu organizáciu, (4) pracujú na báze suprateritoriálnej solidarity. Všetky tieto atribúty sú navzájom prepojené. Jednotlivé formy občianskej spoločnosti môžu mat' globálny charakter len v jednom alebo aj niekol'kých ohl'adoch. Ako príklad tu môžeme uviest' skupinu aktivistov na lokálnej úrovni, ktorí sa snažia o intenzívnejšiu politizáciu globálneho problému klimatických zmien. Takáto skupina je súčastou globálnej občianskej spoločnosti, napriek tomu, že asociácii chýba cezhraničná organizácia a môže skutočne zriedkavo komunikovat' so zahraničnými občianskymi zoskupeniami podobného zamerania. Obrátene, globálne cezhraničné siete aktivistov sa môžu mobilizovat' v prospech lokálneho problému. ${ }^{104}$ Nevyvrátitel’ným zostáva, že z dôvodu rozvoja globálnych komunikačných prostriedkov, prepracovanejšej globálnej organizácii, intenzívnejšej suprateritoriálnej solidarite medzi l'ud'mi a stále viac rezonujúcim globálnym témam sa dnes občianske aktivity odpútavajú od teritoriálneho konceptu vzt'ahu národný štát - spoločnost'.

103 KALDOR, M.: Global Civil Society: An Answer to War. Cambridge: Polity. 2003, s. 15.

104 Napríklad mobilizácia globálnej občianskej spoločnosti v prípade rekonciliácie pomerov v Rwande po genocíde obyvatel'stva v roku 1994. USAID/Rwanda. Civil society in Rwanda: Assessment and Options. Dostupné na internete: http://pdf.usaid.gov/pdf_docs/Pnacm181.pdf 
Globalizácia však so sebou neprináša len explicitné benefity. Š́renie liberálnych hodnôt, proklamácia demokracie, multikulturalizmus sa nestretáva s pozitívnym ohlasom najmä v iných ako 'západne' orientovaných kultúrach. Tento jav je v praxi často sprevádzaný prehlbovaním nerovností, poukazovaním na ekonomické, sociálne rozdiely, novými bezpečnostnými hrozbami a novými formami násilia a kriminality. Globálna občianska spoločnost' preto pre aktivistov znamená aj priestor pre civilizovanie globalizačných procesov a zmierňovanie ich dopadu. Existujú názory, že súčast'ou globálnej občianskej spoločnosti sú aj skupiny aktivistov, ktorí nepropagujú mier, demokraciu, či ludské práva a iné v súčasnosti pozitívne vnímané a progresívne globálne témy. Existujú názory, že tento koncept zahŕn̆a aj skupiny proklamujúce násilie, radikalizmus, vrátane skupín explicitne hlásajúcich sa $\mathrm{k}$ podpore teroristických aktivít, či dokonca $\mathrm{k}$ fašizmu a neonacizmu. ${ }^{105}$ Dôvodom je, že mnohé z nich taktiež spĺńajú kritériá globálne rezonujúcej tematiky, globálnej organizácie, cezhraničnej komunikácie, dokonca aj istej suprateritoriálnej solidarity. Z nášho pohl'adu však s uvedeným nemožno súhlasit', nakol'ko tieto skupiny nespĺńajú d’alšie základné atribúty globálnej občianskej spoločnosti, a tými sú (5) civilizované, legálne a legitímne aktivity. Pokial' by aj bolo možné a logické zahrnút' ich do skupín, združení, či organizácií tvoriacich 'globálnu spoločnost', termín 'občianska spoločnost', z latinčiny 'societas civilis' svojou povahou vylučuje spoločnost' takú, ktorá nekorešponduje s adjektívom 'civilis', teda občiansky, ale aj civilný, civilizovaný, nevojenský, striedmy, vecný, vztahujúci sa nie na trestnoprávne ale občianskoprávne vzt’ahy a činy. ${ }^{106}$

Definícia

Vychádzajúc z vyššie uvedenej analýzy normatívneho rámca konceptu, ako aj $\mathrm{z}$ jeho historickej genézy globálnu občiansku spoločnost' definujeme ako priestor. v ktorom sa jednotlivci, skupiny, združenia a organizácie dobrovol’ne spájajú s ciel'om a.) posilnit' demokratizáciu svetovej politikv, b.) diskutovat' a politizovat' témy, ktoré intenzívne vplývajú na globálnu sociálnu, environmentálnu, bezpečnostnú, ale aj ekonomickú sféru a c.) ovplyvňovat' medzinárodné politické rozhodnutia a právne normy $z$ pozície nachádzajúcej sa mimo formálnvch politických inštitúcií.

105 SCHOLTE, J.A.: Global Civil Society: Changing the World? In: SCHOLTE J.A. CSGR Working Paper No. 31/99, [online]. 1999 [cit. 2018-04-06]. Dostupné na internete: https:// www.unicef.org/socialpolicy/files/Global_Civil_Society_Changing_the_World.pdf

106 Znaky ako legálnost' a legitímnost' môžu byt' spochybňované argumentom, že ani disidentské hnutia strednej a východnej Európy, ktoré sme v predchádzajúcich častiach uviedli do globálnej občianskej spoločnosti sa v aktivitách nezlučovali s vnútroštátnymi predpismi vtedajšieho politického režimu, no disidentské hnutia konali legálne a legitímne z pohl’adu medzinárodného práva. Tým, kto nekonal v súlade s právom a v súlade s ratifikovaným Záverečným aktom Konferencie o bezpečnosti a spolupráci v Európe z roku 1975 bol práve vtedajší politický establišment. 
$\underline{\text { Vplyv }}$

Tak, ako pri skúmaní vplyvu iných subjektov medzinárodných vzt’ahov, aj pri skúmaní vplyvu, ktorý dokáže generovat' globálna občianska spoločnost' je nutné určit' a pomenovat' niekol'ko javov, ktoré sú súhrnne schopné vyvolat' žiadané implikácie a ciel'ový efekt. Jednoducho povedané, na to, aby boli aktivity globálnej občianskej spoločnosti efektívne a úspešné, aby bola svojou činnost'ou schopná ovplyvňovat' dianie na medzinárodnej scéne, musí splnit' niekol'ko podmienok: a.) musí byt' legitímnou morálnou autoritou b.) musí mat' kapacitu byt' profesionálnou vedeckou autoritou.

Aby sa konkrétny subjekt $\mathrm{v}$ rámci globálnej občianskej spoločnosti stal legitímnou morálnou autoritou je nutné naplnit' podmienku reprezentácie určitého 'verejného záujmu' alebo 'všeobecného dobra'. ${ }^{107}$ Nakol'ko definovat' verejný záujem v tomto kontexte nie je jednoduché, budeme vychádzat' z prepozície, že pokial' sa jedná o proklamáciu súkromných záujmov združení, spoločností, či organizácií a je možné ju identifikovat' s presadzovaním súkromných ekonomických či politických ciel'ov, takáto aktivita stráca na morálnej autorite, znižuje sa jej kredibilita a dôveryhodnost'. Na to, aby subjekt splnil danú podmienku, jeho aktivita by sa mala týkat' záležitosti nie len vo verejnom záujme, ale často aj v záujme globálnom. Čo sa týka legitimity konania, v zmysle širšie postavenej liberálnej paradigmy, medzinárodné organizácie, národné štáty a spoločnost' vo všeobecnosti majú tendenciu predpokladat', že čím väčšia je participácia aktérov globálnej občianskej spoločnosti na riešení globálnych problémov, tým sa zvyšuje legitimita týchto riešení. ${ }^{108}$ Takáto situácia sa dosahuje lepšie v prípade, ked' je zachovávaná autonómia občianskej spoločnosti a je ustanovený efektívny kanál pre komunikáciu politických a iných ciel'ov.

V každom prípade, to, že sa aktéri globálnej občianskej spoločnosti stanú legitímnou morálnou, rešpektovanou autoritou nie je jediným kritériom ich vplyvu, či dokonca úspechu. Ten je paralelne podmienený ich kapacitou vystupovat' aj ako profesionálna vedecká autorita. Pre uvedenie príkladu je možné spomenút' organizácie ako Amnesty International, Human Rights Watch alebo Lawyer Committee for Human Rights, ktoré v rámci okruhu svojej činnosti v oblasti l'udských práv a slobôd vystupujú ako autorita, ktorá v istých medzinárodne rešpektovaných kruhoch vyslovene definuje, ktoré konanie porušením l'udských práv je, a ktoré konanie ním nie je. Iné skupiny, organizácie, či dokonca štáty môžu disponovat' informáciami, prípadne ich publikovat' a inak s nimi narábat', no len v prípade, že organizácia typu Amnesty International alebo Human Rights Watch 'legitimizuje' takúto informáciu, je d'alej medzinárodným spoločenstvom vnímaná ako korektná. Taktiež zhromažd'ovanie informácií a ich d’alšie spracovanie podlieha v oboch menovaných organizáciách komplikovaným a striktným procesom. Amnesty International nepracuje s informáciou, ktorá by nebola overená minimálne tromi priamymi zdrojmi a d’alej ju nešíri, pokial' ju neverifikuje centrála organizácie v Londýne. HRW postupuje podobne pri procese

107 FLORINI, A.M. a kol.:Third Force, The Rise of Transnational Civil Society. Carnegie Endowment, 2000.

108 WEISS, T a kol.: The Rise of Non-State Actors in Global Governance, Opportunities and Limitations. [online]. [cit. 2018-04-05]. Dostupné na internete: http://acuns.org/wp-content/uploads/2013/11/ggweiss.pdf 
zhromažd’ovania informácii, no ich šírenie je strategicky podmienené vyvolaním väčšej mediálnej pozornosti. Mnoho západných vlád vrátane USA a Nemecka využívajú pri koncipovaní vlastných ludskoprávnych dokumentov a správ výstupy z výročných, ale aj iných správ týchto organizácí́ takmer doslovne. ${ }^{109}$

Nakol'ko aktéri globálnej občianskej spoločnosti nedisponujú represívnym aparátom, ani ekonomicky produktívnym aparátom, ich vplyv stojí výlučne na ich 'soft' nástrojoch - autorite a legitimite - na legitímnej autorite morálnej a na legitímnej autorite profesionálno-vedeckej. Práve tou sa snažia operovat', zjednodušene povedané, tak, aby presvedčili iných aktérov štátnych alebo neštátnych o oprávnenosti konania svojho alebo v prípade, že sami oprávnení konat' nie sú, urgujú na konanie aktérov, ktoré v danej veci oprávnení a schopní konat' sú. ${ }^{110}$

\section{Globálna občianska spoločnost’ a medzinárodný trestný súd - prípadová štúdia}

\section{1 Úloha a vplyv globálnej občianskej spoločnosti na ustanovenie medzinárodného trestného súdu: dôvody a stimuly jeho vzniku}

Myšlienka ustanovenia jedného permanentného medzinárodného súdu s trestnoprávnou jurisdikciou bola po prvýkrát uvedená po II. svetovej vojne Rezolúciou Valného zhromaždenia Organizácie spojených národov (d’alej aj ako „OSN“) č. 260 z 8. decembra 1948, kedy bol prijatý Dohovor o zabránení a trestaní zločinu genocídy. ${ }^{111}$ Počas nasledujúcich ôsmich dekád bolo medzinárodné spoločenstvo svedkom množstva rozsiahlych konfliktov s katastrofálnymi humanitárnymi dôsledkami. Vysoko očakávaná realizácia pôvodného plánu však prišla až 1. júla 2002, nadobudnutím účinnosti Rímskeho Štatútu. Tento dokument bol prijatý 17. júla 1998 ako právny základ pre vytvorenie Medzinárodného trestného súdu s permanentným sídlom v Haagu (International Criminal Court, d’alej aj ako „MTS“). Medzinárodný trestný súd je prvým svetovým orgánom s univerzálnou, hybridnou jurisdikciou zameraný na trestné stíhanie fyzických osôb, páchatel'ov najzávažnejších medzinárodných zlo-

109 FLORINI, A.M. a kol.: Third Force, The Rise of Transnational Civil Society. Carnegie Endowment, 2000, s. 188.

110 V medzinárodných vzt’ahoch, rovnako ako aj v časti literatúry o transformácii konfliktov je možné nájst' rozdelenie medzi " hard power/ tvrdými " a " soft power/ mäkkými" silami/ nástrojmi politiky, ktoré bolo uvedené Josephom Nye (2004). Oba termíny sú používané hlavne prívržencami realistickej školy medzinárodných vzt’ahov. Tvrdými nástrojmi sa rozumejú nástroje príkazu, donútenia, použitie silových riešení. Koncept 'cukor a bič', ktorý bude d'alej v práci spomínaný, je tiež blízko spätý s týmto prístupom. Soft power politika znamená schopnost' ovplyvnit' iného aktéra rôznymi, zvyčajne nemateriálnymi prostriedkami. Táto je v teórií často spájaná s prostriedkami, ktorými operujú aktéri občianskej spoločnosti. Zasahujúci sa tu snaží o presvedčenie strán, nie ich donútenie na určité opatrenie s použitím symbolických prostriedkov, akými sú napríklad prestíž, autorita a rešpekt. Pozri bližšie: Miall - Ramsbotham - Woodhouse, 1999; Nye, 2004.

111 Predhovor Dohovoru o zabránení a trestaní zločinu genocídy: „Uvedomenie, že genocída spôsobila l'udstvu vo všetkých obdobiach dejín vel'ké straty a v presvedčení, že k oslobodeniu l’udstva od tak odpornej metly je nevyhnutná medzinárodná spolupráca“. 
činov ako zločin genocídy, zločinov proti ludskosti, vojnových zločinov a agresie. ${ }^{112}$ Zámerom vytvorenia tejto stabilnej a stálej inštitúcie bolo spravodlivo potrestat' osoby zodpovedné za spáchané násilnosti a tiež poukázat' na to, že neexistuje nerozhodnost' a strach medzinárodného spoločenstva čelit' potenciálnym budúcim páchatel'om medzinárodných trestných činov. Za hlavnú motiváciu je možné označit' neschopnost' povolaných autorít konat' a poskytnút' uspokojivú reakciu na medzinárodné zločiny spáchané v priebehu 20. storočia, no taktiež poburujúci počet činov, ktoré zostali a stále zostávajú nepotrestané práve $\mathrm{z}$ dôvodu komplikovanosti, nejednotnosti vnútroštátnych trestnoprávnych predpisov, no mnohokrát aj $\mathrm{z}$ dôvodu neochoty a nevôle konat' zo strany štátu.

Ako bolo uvedené, myšlienka bola vyjadrená už v roku 1948, no vlastné znovu oživenie konceptu ustanovit' jeden stály, medzinárodný súd prišlo v roku 1989, ked' Trinidad a Tobago vyjadrilo potrebu riešit' problematiku medzinárodného obchodu s drogami. ${ }^{113}$ Valné zhromaždenie OSN poverilo Medzinárodnú Právnu Komisiu/ International Law Commission (d’alej aj ako "ILC") vypracovaním projektu: funkcií, jurisdikcie, kompetencií, ako aj predbežného návrhu Rímskeho Štatútu. V roku 1993 prizvala ILC štáty na pripomienkové konanie $\mathrm{k}$ jeho prvému konceptu a v roku 1994, neštandardne rýchlo ukončila svoju činnost' a vyzvala štáty na pristúpenie $\mathrm{k}$ dopracovanému návrhu. Napriek tomu, že niektoré európske a karibské štáty podporovali myšlienku založenia súdu v čo najkratšom časovom období, iní členovia Valného zhromaždenia OSN váhali. Zo zástupcov štátov bola vytvorená ad hoc komisia, ktorá mala za úlohu opätovne preskúmat predložený návrh. ${ }^{114} \mathrm{O}$ rok neskôr bola táto ad hoc komisia pretransformovaná na oficiálnu prípravnú komisiu (d’alej aj ako "PrepCom"). Na konci roku 1996 bolo po dosiahnutí kompromisu dovtedy nejednotných štátov pevne a nemenne stanovené obdobie a miesto konania konferencie: Rím, leto roku 1998.

V rokoch 1993 - 1996 bolo možné sledovat’ vznik skupiny spoločne zmýšlajúcich štátnych delegátov, ${ }^{115}$ silne podporovaných niekol'kými mimovládnymi organizáciami, ktorých cielom bolo promptné založenie súdu. ${ }^{116}$ Oponentov tohto spolku však tvorili stáli členovia Bezpečnostnej rady OSN a členovia Hnutia nezúčastnených krajín rovnako jednotne neochotných podporit' nezávislý súd s nadnárodnými prá-

112 Článok 5 Rímskeho Štatútu.

113 NOONE, G. P. - MOORE, W. D.: An introduction to the International Criminal Court. In: Naval Law Review, s. 112.

114 CRAWFORD, J.: The Work of the International Law Commission. Oxford University Press. 2002, s. 24.

115 Zoznam štátov bezprostredne podporujúcich založenie ICC: Andorra, Argentína, Austrália, Rakúsko, Belgicko, Benin, Bosna-Hercegovina, Bruneji, Bulharsko, Burkina Faso, Burundi, Kanada, Čile, Kongo (Brazzaville), Costa Rica, Chorvátsko, Česká republika, Dánsko, Egypt, Estónsko, Fínsko, Gabon, Georgia, Nemecko, Ghana, Grécko, Mad’arsko, Írsko, Taliansko, Jordán, Litva, Lesotho, Lichtenštajnsko, Lotyšsko, Luxemburg, Malawi, Malta, Namíbia, Holandsko, Nový Zéland, Nórsko, Filipíny, Pol'sko, Portugalsko, Kórejská republika, Rumunsko, Samoa, Senegal, Sierra Leone, Singapur, Slovenská republika, Slovinsko, Solomonove ostrovy, Južná Afrika, Španielsko, Swaziland, Švédsko, Švajčiarsko, Trinidad a Tobago, Vel'ká Británia, Venezuela a Zambia (Schabas, 2004, s. 16).

116 SCHABAS, W. A.: An Introduction To The International Criminal Court. Cambridge University Press. 2004, s. 481. 
vomocami. ${ }^{117} \mathrm{~V}$ roku 1995 niekol'ko mimovládnych organizácii monitorujúcich komunikáciu Valného zhromaždenia OSN a ILC vytvorilo Koalíciu pre Medzinárodný trestný súd (d'alej aj ako "CICC"). Hlavným ciel'om CICC bolo obhajovat', podporit' a dopomôct' $\mathrm{k}$ ustanoveniu efektívneho a spravodlivého medzinárodného trestného súdu. Táto iniciatíva postupne prerástla do skupiny viac ako dvoch a pol tisícky občianskych združení, skupín, spoločenstiev, koalícií a mimovládnych organizácií, ktoré svojou koordinovanou činnost'ou, napriek vel'kým diverzifikáciám v pôvodných zameraniach a základoch značnou mierou ovplyvnili vznik súdu.

V súčasnosti je CICC jedným z najrozsiahlejších partnerstiev spoločností vo svete zahŕňajúcich organizácie občianskej spoločnosti z viac ako 150 krajín. Je tiež vedúcim telesom v globálnom boji proti medzinárodným trestným činom genocídy, vojenským zločinom, zločinom proti l'udskosti, agresie, presadzujúce myšlienku rešpektu k l'udským právam a spravodlivosti. Jej predsedom je bývalý Generálny tajomník OSN a laureát Nobelovej ceny za mier, Kofi Annan. Koalícia stála v čele globálneho úsilia občianskej spoločnosti o vytvorenie Medzinárodného trestného súdu a momentálne sa podiel'a na zabezpečovaní jeho efektivity, nezávislosti, ako aj dostupnosti a vynútitel’nosti noriem medzinárodného práva. Zároveň sa snaží o promptné reakcie $\mathrm{k}$ čoraz naliehavejším výzvam lokálneho a regionálneho rozvoja. CICC koná od počiatku v rámci všetkých aspektov a dimenzií súdu, spolupracuje so širokým spektrom národných vlád, OSN, ako aj s d’alším inštitúciami a medzivládnymi organizáciami, ktoré sú zapojené do siete medzinárodného justičného systému. Prostredníctvom tohto striktne koordinovaného globálneho partnerstva je hlavnou úlohou CICC dohliadat' na to, aby bola pre obete najzávažnejších zločinov dosiahnutel'ná spravodlivost'. Prípad založenia Medzinárodného trestného súdu je možné označit' ako výsledok vplyvu globálnej občianskej spoločnosti a úlohu CICC v kooperácii jednotlivých štátnych aktérov za primárnu pri vzniku tohto jedinečného súdu.

\subsection{Aktéri globálnej občianskej spoločnosti participujúci na založení Medzinárodného trestného súdu v Haagu}

\section{Organizácie zamerané na ochranu l’udských práv}

Organizácie zamerané na ochranu l’udských práv sú svojím zastúpením v koalícií obzvlášt' prevládajúce. Po desat'ročia trvajúcich prácach na budovaní komplexného medzinárodného systému na ochranu l'udských práv a slobôd na regionálnej, ako aj globálnej úrovni si experti na túto problematiku začali uvedomovat', že zatial' čo koncepcia hmotného práva na ochranu l’udských práv a slobôd dostáva jasný rámec, rozsah ich porušení vo svete nemá klesajúci charakter. „Boj proti beztrestnosti“ sa stalo hlavným mottom jednotlivých iniciatív. Skúsenosti v mnohých Latinsko-Amerických a iných krajinách však napriek prechodu na demokratický systém vlády poukazovali na fakt, že nie len právne, ale taktiež sociálne, psychologicky a politicky je stíhanie medzinárodných zločincov z minulých režimov vel'mi zložité.

117 Medzi hlavných oponentov prijatia Rímskeho Štatútu patrili: USA, Č́na, Líbya, Sýria, Irak, Irán. 
Idea založenia permanentného, nezávislého medzinárodného trestného súdu sa pre ludskoprávne organizácie stala $\mathrm{v}$ danom čase jednou z dominantných. Ad hoc tribunály v Norimbergu, Tokiu, ale aj Juhoslávii a Rwande boli na jednej strane považované za vzory, na ktorých by bolo možné ideologicky, ale aj hmotnoprávne postavit' jurisdikciu spoločného stáleho súdu. ${ }^{118} \mathrm{Na}$ strane druhej však boli mnohými aktérmi považované za spolitizované a kritizované za politickú selektívnost' práve z dôvodu, že ich ustanovenie bolo v moci len niekol'kých štátov, primárne z radov permanentných členov Bezpečnostnej rady OSN, pričom sa trestné stíhania viedli len v niekol'kých vymedzených situáciách. Mnoho kritiky bolo vyslovenej z radov profesionálnych medzinárodných právnikov, politikov, ale aj akademikov a žurnalistov z dôvodu nízkej efektivity tribunálov, nepružného konania, nehospodárnosti, teda vysokých nákladov na ich funkcie, ktoré muselo znášat' celé medzinárodné spoločenstvo v rámci OSN. Funkciami tu máme na mysli aj náklady na vyšetrovacie úkony, zabezpečenie dôkazov, personálne náklady pre medzinárodné tímy vyšetrovatel’ov vrátane cestovných nákladov a iných funkčných nákladov často vynakladaných roky po tom, ako sa skutky považované za trestné stali. Procesné pravidlá boli skostnatené, byrokratické a skutočne často zabraňovali promptnej reakcii, ktorá by bezprostrednému ohrozeniu mieru a bezpečnosti v danej situácii zabránila. ${ }^{119}$ Opatrný a časovo náročný legislatívny, ale aj politický postup $\mathrm{k}$ založeniu permanentného súdu bol preto legitímnou súčast'ou medzinárodných rokovaní, nakol'ko sa pri nich skutočne vychádzalo $\mathrm{z}$ reálnych skúseností z fungovania uvedených Ad hoc tribunálov.

Všetky klúčové globálne organizácie presadzujúce ochranu l'udských práv a základných slobôd zahŕňajúce Amnesty International, Human Rights Watch, International Commission of Jurists, ako aj Federation International des Ligues de Droits de l'Homme boli do týchto rokovaní aktívne zapojené. Iné regionálne a národné organizácie ako napríklad European Roma Rights Centre, Arab Commission on Human Rights, Argentinian Asamblea Permanente de Derechos Humanos, Ligue Rwandaise pour la Promotion et la Défense des Droits de l'Homme a Cambodian Human Rights Task Force zohrali v uvedenej iniciatíve taktiež zásadnú úlohu. Okrem nich sa do boja o zefektívnenie vymáhania noriem medzinárodného trestného práva vo forme permanentného súdu zapojili akademici z oblasti l’udských práv, právnici špecializovaní v l'udsko-právnej oblasti, či iní, individuálni aktivisti. Nakol'ko v minulosti neexistovala podobná inštitúcia, dokonca ani tradícia, či všeobecná vôla, ustanovenie medzinárodného trestného súdu $\mathrm{s}$ kompetenciou stíhat' fyzické osoby a nie štáty v prípade porušenia medzinárodnoprávnej trestnej legislatívy samozrejme vyžadovalo okrem iného, nie jednoduché zjednotenie názorov na problematiku tak zo strany legislatívnej, ako aj politickej.

118 SCHABAS, W. A.: An Introduction To The International Criminal Court. Cambridge University Press. 2004, s. 481.

119 Pre uvedenie iného príkladu z minulosti, kritika Norimberských procesov okrem iného, $\mathrm{v}$ prvom rade vyzdvihovala fakt, že proces bol legálne založený na ex post facto princípe, ktorý hrubo porušil zvykové právo, ako aj medzinárodné dohody. Ide o princíp, na základe ktorého nie je možné stíhat', dokonca ani považovat' za trestný taký čin, ktorý v čase jeho spáchania trestným nebol ani podl’a vnútroštátneho, ani podl'a medzinárodného práva. Ďalšími negatívnymi faktami sú nedostatok procesných pravidiel v Charte, žiadna možnost' odvolania sa voči rozsudku, nedostatočná ochrana práv obvineného a všeobecne rozsiahle zlyhanie pri rešpektovaní základných princípov trestného práva, tak ako práva na spravodlivý proces alebo princípu nullum crimen sine lege nulla poena sine lege. 
Organizácie skupín žien

Skupiny ženských organizácií, ktoré sa zapojili do Koalície boli primárne inšpirované a motivované prípadom juhoslovanského Tribunálu (d’alej aj ako „ICTY“). Vzhl'adom $\mathrm{k}$ tomu, že aj v minulosti často poukazovali na skutočnost', že sa počas ozbrojených konfliktov stávali práve ženy často zneuživanou, zranitel'nou skupinou, pričom sa znásilnenia stali jedným z nástrojov etnického vyhladzovania v bývalej Juhoslávii, táto problematika bola následne uvedená nie len do pozornosti Koalície. ${ }^{120}$ Hoci štatút ICTY neobsahoval mandát s rodovým rozdelením, jeho funkcionári časom uznali, že zjavne rodovo neutrálny justičný systém logicky nemôže riešit' zločiny s rozličnými rodovými špecifikami. Na zretel' teda boli vzaté aj niektoré z požiadaviek spomínaných skupín žien. Bol menovaný splnomocnenec pre rodové otázky v rámci úradu prokurátora Medzinárodného trestného súdu. Následne bolo rozhodnuté o povolení obetiam znásilnení svedčit' v trestnom konaní anonymne, ako aj seriózne stíhat' znásilnenie ako zločin proti l'udskosti - otázka, ktorou bol prvý prokurátor MTS, Richard Goldstone, špeciálne zaujatý. ${ }^{121}$

Skutočnost', že sa po prvýkrát kodifikovala rodová problematika do noriem humanitárneho práva spočívala $\mathrm{v}$ aktivite a iniciatíve žien z bývalej Juhoslávie a ich európskych podporovateliek. Na tejto skúsenosti neskôr stavali na konferenciách v Ríme a New Yorku.

Viac globálnou skúsenost'ou pre ženské skupiny možno nazvat' účast' na Svetovej konferencii o l’udských právach vo Viedni roku 1993 a IV. svetovej konferencii o ženách, ktorá sa konala $\mathrm{v}$ Pekingu v roku 1995. ${ }^{122}$ Jednalo sa o konferencie, ktorých výstupom neboli záväzné medzinárodné zmluvy. V každom prípade však výzvou pre organizácie na ochranu ženských práv zostávalo prijatie vlastných progresívnych návrhov do ambicióznych finálnych deklarácií vo vyjednávaniach o ustanovenie MTS.

Zatial', čo niektoré ženské skupiny, ako napríklad Equality Now boli do rokovaní zapojené už od roku 1995, väčšina sa k procesu pridala až neskôr. Woman's Causus for Gender Justice sa vyformovala ako malá skupina aktivistiek pre ženské práva vo februári roku 1997 v priebehu zasadnutí PrepCom, ked’že si uvedomili, že bez väčšej snahy nebudú mat' rodové otázky vo vyjednávaniach adekvátne zastúpenie. ${ }^{123}$ Vel'mi rýchlo sa skupina rozrástla do koalície v rámci Koalície CICC s viac ako 300 členskými organizáciami v čase konania Rímskej konferencie. ${ }^{124}$

120 STEAINS, C.: 'Gender Issues'.Negotiations, Results. 1999, s. 359.

121 SHARRATT, S. - KASCHAK, E.: Assault on the Soul: Women in the Former Yugoslavia. Haworth. Press: 1999, s. 176.

122 STEAINS, C.: 'Gender Issues'.Negotiations, Results. 1999, s. 359. GLASIUS, M.: The International Criminal Court: A Global Civil Society Achievement. Routledge, 2006, s. 186.

123 Tak ako v Pekingu a na iných fórach, feministická väčšina ženských skupín zameraná na obhajobu ženských práv na rokovaniach v New Yorku a Ríme pravidelne narážala na menšinové skupiny obhajcov „,práv rodinných“. Tieto skupiny boli silne podporované Vatikánom a Arabskými štátmi a ich primárnym záujmom bolo zabránit', aby sa do Rímskeho Štatútu dostala akákol'vek terminológia, ktorá by mohla byt' interpretovaná ako zl'ahčovanie potratov, resp. umelého prerušenia tehotenstva.

124 GLASIUS, M.: The International Criminal Court: A Global Civil Society Achievement. Routledge, 2006, s. 186. 


\section{Mierové organizácie}

Ciele menších mierových kontingentov v rámci iniciatívy pre založenie MTS boli menej jasné. Jednalo sa o zastúpenie dvoch typov mierových skupín. Prvou skupinou, reprezentovanou napríklad Nuclear Age Peace Foundation a International Association of Lawyers against Nuclear Arms boli priamy nástupcovia odzbrojovacieho hnutia z 80 . rokov minulého storočia. Ich primárnym záujmom bola implementácia hrozby použitia alebo samotného použitia jadrových zbraní do charakteristických znakov vojnového zločinu. Táto iniciatíva v Ríme úspešná nebola. Druhá skupina, reprezentovaná napríklad International Alert or the Helsinki Citizens' Assembly mala korene v rovnakom hnutí, no vyvíjala sa $v$ inom smere prostredníctvom priamej zaangažovanosti v nejadrových konfliktoch 90. rokov, pri ktorých sa civilné obyvatel'stvo stalo primárnou metódou vedenia vojny. Skúmali riešenia tzv. grass-roots konfliktov, e.i. tých, ktoré sú vedené prostým l'udom, resp. masami obyvatel'stva. Ďalej sa zaoberali príslušnými rezolúciami bezpečnostných orgánov na jednej strane, ako aj hlbším l’udsko-právnym prístupmi $\mathrm{k}$ danej problematike na strane druhej. Ich záujmy však boli v skutočnosti vel'mi podobné tým, ktoré presadzovali skupiny na ochranu l'udských práv a slobôd. ${ }^{125}$

\section{Organizácie propagujúce ideu konceptu globálnej governmentality}

Nie vel'ké, no vel'mi aktívne skupiny, ktoré môžu byt' charakterizované aj ako „global governance“ alebo skupiny pre globálnu governmentalitu sú angažované všeobecne $\mathrm{v}$ propagovaní demokratickejšieho a spravodlivejšieho globálneho poriadku. ${ }^{126} \mathrm{~V}$ rámci rozpracovanej témy však zahŕňajú svetových federalistov, ako aj rôzne asociácie napojené na OSN, ktoré napriek podrobnému monitoringu a vel'kej dávke kritiky propagujú ideu silnej OSN. Ďalej je do tejto skupiny možné zaradit' tri navzájom prepojené, čiastočne medzinárodné, čiastočne talianske organizácie so silným napojením na politické elity: Parliamentarians for Global Action, Transnational Radical Party a predovšetkým No Peace Without Justice. ${ }^{127}$

Tieto skupiny si našli svoje miesto a prispeli k riešeniu niektorých menej sporných otázok v Štatúte. Svetoví federalisti, napríklad, zosumarizovali postavenie štátov a mimovládnych organizácií pri financovaní súdu, pričom preskúmavali skúsenosti z iných medzinárodných ad hoc tribunálov a súdov. Utvorili tak konkrétny návrh, ktorý zdôrazňoval, že napriek tomu, že sa to javí ako marginálny problém, súd nebude

125 KALDOR, M.: The Idea of Global Civil Society. 2003, s. 583-593.

$126 \mathrm{~V}$ širšom slova zmysle je termín používaný na označenie všetkých predpisov, regulácií zameraných na organizáciu a centralizáciu l’udských spoločností na globálnej úrovni. Globálna governmentalita - je kolektívna snaha o identifikáciu, pochopenie a riešenie celosvetových problémov, ktoré prekračujú kapacity riešenia na úrovni štátu, prípadne kombinácia neformálnych a formálnych ideí, hodnôt, procesov, konaní, politík a organizácií, ktoré napomáhajú všetkým aktérom - štátom, medzivládnym organizáciám, globálnej občianskej spoločnosti a jednotlivcom - identifikovat', porozumiet' a navrhnút' riešenie pre cezhraničné problémy. Je to súbor otázok, ktoré umožňujú riešit', ako svet je, bol a ako by mohol byt' ovládaný. (Weiss a kol., 2013, s. 6)

127 BENEDETTI, F. - WASHBURN, J.: Drafting the International Criminal Court Treaty: Two Years to Rome and an Afterword on the Rome Diplomatic Conference. 1999, s. 22. 
schopný efektívnej a úspešnej činnosti bez adekvátnych finančných prostriedkov. ${ }^{128}$ Tento návrh sa objavil viac ako rok predtým, ako štáty alebo Sekretariát OSN vytvorili akýkol'vek dokument týkajúci sa financovania súdu. Prínos tejto iniciatívy bol komentovaný a pozitívne hodnotený mnohými delegátmi počas stretnutí PrepCom. ${ }^{129}$

\section{Náboženské skupiny}

Medzi d’alších z radov zástupcov globálnej občianskej spoločnosti možno zaradit' zástupcov cirkví a náboženských skupín, vrátane mnohých dominantných krestanských vierovyznaní, ale taktiež Židovských, Moslimských a Budhistických federácií. Jedným z dôvodov zapojenia sa členov cirkví a náboženských skupín do iniciatívy bol fakt, že primárnym ciel'om MTS nebolo len samotné potrestanie páchatel'ov medzinárodných trestných činov, ale aj ochrana, kompenzácia, či odškodnenie pre obete a resocializácia, ak vôbec možná, pre zločincov.

Členovia týchto náboženských skupín vel'mi rýchlo dosiahli konsenzus o potrebe väššej pozemskej spravodlivosti, existujúcej popri tej večnej, božskej spravodlivosti. Ich zámerom bolo íst' nad rámec samotného potrestania, od pôvodného ciel'a trestnej justície $\mathrm{k}$ justícií restoratívnej, a teda pomôct' uzmierit' komunity rozorvané násilím a zaviest' duchovný rozmer do projektu ustanovenia MTS. Väčšina z týchto organizácií vytvorila samostatnú koalíciu pod menom Faith-Based Caucus. ${ }^{130}$ Táto koalícia sa zameriavala na znenie preambuly a finálnych klauzúl Štatútu tak, aby boli orientované menej politicky a viac eticky a morálne, stále v kontexte náboženskej spirituality. ${ }^{131}$

\section{Skupiny právnikov a právnych expertov}

Nakoniec, nakol'ko je otázka založenia nezávislého, stáleho súdu s medzinárodnou trestnou jurisdikciou nielen otázkou iniciatívy, vplyvu a konsenzu štátnych a neštátnych aktérov, ale predstavuje vážny precedens v právnej rovine, realizácia tohto projektu vyžadovala niekol'koročnú systematickú prácu právnych špecialistov. V zásade sa jedná o konvergenciu rôznych oblastí práva, ako medzinárodné právo verejné, vrátane medzinárodnej ochrany l'udských práv a slobôd, humanitárneho práva, dovtedy existujúcich medzinárodných trestných noriem a práva medzinárodných organizácií s prienikom do práva európskeho či národného, ako je trestné právo hmot-

128 SWEENEY, D.M.: Prospects for the Financing of an International Criminal Court. Institute for Global Policy. 1996.

129 DURHAM, H.: Women and Civil Society: NGOs and International Criminal Law. Transnational Publishers. 2004, s. 350.

130 Členovia Faith-Based Caucus: American Jewish Committee/ Jacob Blaustein Institute for the Advancement of Human Rights American Humanist Association, Baha'i's of the United States, Church World Service, Evangelical Lutheran Church in America, Fellowship of Reconciliation Loretto Community, Maryknoll Office for Global Concern, National Council of Churches of Christ in the USA, The National Service Conference of the American Ethical Union, Presbyterian Church USA, Soka Gakkai International Temple of Understanding, Unitarian Universalist Association, United Methodist Church, World Council of Churches.

131 CLARK, R. S. - SLADE, T. N.: Preamble and Final Clauses. Negotiations, Results. 1999, s.421450. 
né a procesné, či pravidlá extradície. Všetky jednotlivé normy a pravidlá, národné, regionálne a medzinárodné sú $\mathrm{v}$ súčasnosti spoločne zjednotené v kompaktnom Rímskom Štatúte s vlastnými procesnými normami a jedinečným mandátom. Naviac sú tu zjednotené rôzne právne systémy štátov s kontinentálnou/civilnou a anglo-americkou právnou tradíciou tak, že je Štatút tvorený tzv. hybridným právnym systémom. Ten sa zakladá na hmotných, písaných normách na báze práva kontinentálneho, no v procese sa prihliada aj na precedensy a judikáty $\mathrm{z}$ oblasti iných medzinárodných súdov a tribunálov. Nie je teda prekvapujúce, že idea ustanovenia MTS prilákala množstvo právnych expertov, teoretikov, či l'udí z praxe, nakol'ko zostavit' legitímny systém, právne vymožitel'ný, efektívny a kompaktný v rámci jednej 'medzinárodnej multilaterálnej zmluvy' bolo skutočne nóvum $\mathrm{v}$ oblasti medzinárodného, nie len trestného práva. Vo fáze mobilizujúcej sa globálnej občianskej spoločnosti pre iniciatívu založenia permanentného medzinárodného trestného súdu teda právna obec nechýbala, pričom zohrala aj z legislatívneho postavenia a štruktúry súdu zásadnú úlohu.

Metódy a formy činnosti aktérov participujúcich na založení Medzinárodného trestného súdu v Haagu

Medzi hlavné aktivity organizácií, koalícií a jednotlivcov zapojených do kampane pre vznik Medzinárodného trestného súdu patria:

- lobbing u vládnych reprezentantov, štátnych orgánov, delegácií, misií;

- vypracovávanie expertných správ, dokumentov, podkladových materiálov, analýz, prípadne vedeckých článkov;

- zvolanie a organizácia seminárov, konferencií, odborných workshopov, diskusných panelov so zástupcami štátov, či medzinárodných organizácií;

- hladanie a poskytovanie finančnej podpory pre mimovládne organizácie $\mathrm{z}$ rozvojových krajín a expertná účast' $\mathrm{v}$ diskusiách s nimi;

- poskytovanie špecialistov v rôznych odboroch a interných stážistov menším a chudobnejším vládnym delegáciám;

- mediálna kampaň.

\section{Záver}

Uviedli sme vymedzenie konceptu globálnej občianskej spoločnosti z teoretického hladiska, poukázali na nejednotnost' $\mathrm{v}$ jeho nocionálnej interpretácii a upozornili na skutočne široké spektrum náhl’adov, cez ktoré sa dá pristupovat' $\mathrm{k}$ jeho výskumu. $Z$ uvedeného sme abstrahovali optiku, cez ktorú je možné vo výskume globálnej občianskej spoločnosti pristupovat' z hl'adiska medzinárodných vzt’ahov a medzinárodného práva. Aj vd'aka čiastkovým výskumom uvedených $\mathrm{v}$ druhej časti bolo možné elaborovat' definíciu pre pojem globálna občianska spoločnost' a vyextrahovat' jej podstatné charakteristické znaky. Následne sme upriamili pozornost' na jej vplyv a dve základné podmienky, ktoré ako premenné priamo úmerne určujú intenzitu a mieru vplyvu aktérov globálnej občianskej spoločnosti.

Ako poslednú, záverečnú špecifikáciu výskumu globálnej občianskej spoločnosti, považujeme za podstatné explicitné vylúčenie istej formy podtextu, ktorý s ohl'adom 
na iné, možné aspekty tejto témy daný výskum môže evokovat'. Na jednej strane totiž existujú lokálne aktívni aktéri, ktorí vytvárajú koalície prostredníctvom transnacionálnych sietí, no preferujú priamu formu činnosti a vplyvu nie s ciel'om reformovat', ale s ciel'om suplementovat', podporit' existujúci systém alebo iný establišment. Ich aktivity možno označit' aj za nie priamo politické, bez ambície systém menit', ale s primárnou ambíciou systém dopíňat'. Na druhej strane však existujú také medzinárodné, profesionálne občianske spoločnosti, ktoré majú tendenciu preferovat' politické aktivity mierené voči globálnym inštitúciám, ustanoveniam, aktérom alebo aj systémom. Ich ciel'om je napravit' alebo vylepšit', reformovat', prípadne ustanovit' a založit' to, čo na globálnej platforme inštitucionálne alebo systémovo chýba. ${ }^{132}$ Pre liberálov a konštruktivistov ${ }^{133}$ sa kampane týchto aktérov stali akýmsi emblémom a tiež vel'mi silným argumentom pre poukázanie na evolúciu svetovej politiky smerom k pluralistickému, viac normatívnemu, multilaterálnemu a ultimatívne demokratickejšiemu systému, ktorý nasledoval po konci studenej vojny a tiež pre posilnenie konceptu globálnej governmentality. ${ }^{134}$ Pre účely tejto štúdie však podtext globálnej občianskej spoločnosti ako pilier politickej teórie globálnej governmentality nie je relevantný a ani žiadúci. Aktivity oboch skupín aktérov globálnej občianskej spoločnosti s dosahom na medzinárodné vzt’ahy, na politiku, na medzinárodné právo a podobne, nepovažujeme za priame. Nakol'ko títo aktéri nedisponujú legislatívnou ani výkonnou mocou, či už na úrovni lokálnej, regionálnej alebo medzinárodnej, nemožno od nich očakávat' priamy výkon konkrétnych opatrení na riešenie stanoveného problému. V oblasti medzinárodnej politiky platí uvedená téza súhlasne. Zo svojej podstaty dokážu evidentne ovplyvňovat', ale nie suplementovat' rozhodovacie procesy politických elít. Napriek diskusiám o globálnej govermentalite, ktorých súčast'ou sú aj diskurzy o vplyve globálnej občianskej spoločnosti, governmentalita, per se, nie je predmetom tejto práce, napriek tomu, že určité výstupy a argumenty by sa pre tézy

132 Pozri bližšie: FALK, R.: The United Nations and Cosmopolitan Democracy: Bad Dream, Utopian Fantasy, Political Project. In: ARCHIBUGI, D. - HELD, D. - KÖHLER, M.: ReImagining Political Community: Studies in Cosmopolitan Democracy. Stanford: Stanford University Press, 1998. s. 309-332.; SCHOLTE, J.A.: Global Civil Society: Changing the World? In : SCHOLTE J.A.: CSGR Working Paper No. 31/99, [online]. 1999 [cit. 2018-04-06]. Dostupné na internete: <http://home.aubg.edu/faculty/mtzankova/POS\%20102\%20Readings/ Scholte_Global\%20Civil\%20Society.pdf>; WEISS, T a kol.: The Rise of Non-State Actors in Global Governance, Opportunities and Limitations. [online]. 2013, [cit. 2018-04-05]. Dostupné na internete: $<$ http://acuns.org/wp-content/uploads/2013/11/gg-weiss.pdf $>$

133 Prístupy k skúmaniu medzinárodných vzt’ahov: liberálny a idealisticko - konštruktivistický podla CHANDLER, D. - BAKER, G.: Global Civil Society: Contested Futures (Routledge Advances in International Relations and Global Politics. London: Routledge, 2004, kapitola 3.

134 KECK, M. - SIKKINK, K.: Transnational Networks on Violence against Women. In: KECK, M. - SIKKINK, K.: Activists beyond Borders: Advocacy Networks in International Politics. Ithaca, NY: Cornell University Press. 1998. 228 s.; KEOHANE, R.O. - NYE, J. S. Jr.: Power and Interdependence in the Information Age. In: Foreign Affairs. 1998, vol. 77, no. 5, s. 81-94.; FLORINI, A.M. a kol.: Third Force, The Rise of Transnational Civil Society. Carnegie Endowment, 2000. 295 s.; KALDOR, M.: Global Civil Society: An Answer to War. Cambridge: Polity. 2003.189 s., KALDOR, M.: The Idea of Global Civil Society. In International Affairs, 2003, roč. 79, č.3, s. 583-593.; NYE, J. 2004. Soft Power: The means to success in world politics. Public Affairs. $191 \mathrm{~s}$. 
nástupu globálnej governmentality použit' dali. Ciel’om štúdie nie je dokázat' nástup nového, ekvivalentného aktéra v medzinárodných vzt’ahoch, ani odklon od Vestfálskeho systému.

Ciel'om štúdie bola teoretická demonštrácia a verifikácia samotnej existencie, relevancie a teoretických východísk globálnej občianskej spoločnosti. Globálnu občiansku spoločnost' definujeme ako priestor, v ktorom sa jednotlivci, skupiny, združenia a organizácie dobrovol’ne spájajú s ciel’om a.) posilnit' demokratizáciu svetovej politiky, b.) diskutovat' a politizovat' témy, ktoré intenzívne vplývajú na globálnu sociálnu, environmentálnu, bezpečnostnú, ale aj ekonomickú sféru a c.) ovplyvňovat' medzinárodné politické rozhodnutia a právne normy z pozície nachádzajúcej sa mimo formálnych politických inštitúcií. Globálna občianska spoločnost' v tomto kontexte teda zahíňa občianske aktivity, ktoré: (1) majú záber na globálne rezonujúce témy, (2) vyžadujú cezhraničnú komunikáciu, (3) majú globálnu organizáciu, (4) pracujú na báze suprateritoriálnej solidarity, (5) vykonávajú civilizované, legálne a legitímne aktivity.

\section{Literatúra:}

- ALEXANDER, J.C. "Introduction." Real Civil Societies. London and Thousand Oaks, CA, 1998, s. 1-19.

- ALEXANDER, J.C. The Civil Sphere. Oxford and New York: Oxford University Press, 2006, s. 23-36.

- ANHEIER, H. K. - KALDOR, M- GLASIUS, M. Introducing Global Civil Society In: ANHEIER, H.K. - KALDOR, M. - GLASIUS, M. Global Civil Society. Oxford: Oxford University press, 2001, s. 3-22. ISBN 9780199246441.

- ANHEIER, H.K. A Dictionary of Civil Society, Philanthropy and the Third Sector London: Routledge, 2005, 320 s. ISBN: 9781135355975.

- ARATO, A.- COHEN, J.L. Civil Society and Political Theory. MIT Press, 1994, 771s. ISBN: 0262531216.

- AXTMANN, R. Liberal Democracy Into the Twenty-first Century: Globalization, Integration and the Nation-state, Political analyses. Manchester University Press. 1996, 198 s. ISBN: 0719043050.

- AXTMANN, R. Understanding Democratic Politics: An Introduction. SAGE 2003, 339 s. ISBN: 9780761971825.

- BAYLIS, J. - SMITH, S. - OWENS, P. The Globalization of World Politics. Oxford: Oxford University Press, 2011, 636 s. ISBN: 9780199569090.

- BENEDETTI, F. - WASHBURN, J. Drafting the International Criminal Court Treaty: Two Years to Rome and an Afterword on the Rome Diplomatic Conference. In: Global Governance, ISSN: 10752846, 1999, vol. 5. s. 1-37.

- BERGSTASSER, L. Geschichte der Politischen Parteien in Deutschland. In: Kulašik, P. Liberalizmus. Banská Bystrica: UMB 1998.

- BOBBIO, N. Democracy and Dictatorship: The Nature and Limits of State Power. Minneapolis: University of Minnesota Press, 1989, ISBN: 0745603947.

- BOYD R. Adam Smith on civility and civil society. In: BERRY CH. - PAGANELLI M.P. - SMITH C. The Oxford Handbook of Adam Smith. Oxford: Oxford university press 2013, s. 443-463. ISBN: 0191654663. 
- CHANDLER, D. - BAKER, G. Global Civil Society: Contested Futures (Routledge Advances in International Relations and Global Politics).London: Routledge, 2004, 220 s. ISBN: 978-0415354806.

- CHATTERJEE, P. Lineages of political society: Studies in postcolonial democracy. Columbia University Press 2011, 296 s. ISBN: 9780231158138.

- CLARK, R. S. - SLADE, T. N. 'Preamble and Final Clauses', in Roy S. Lee (ed.), The International Criminal Court: The Making of the Rome Statute; Issues, Negotiations, Results. 1999, The Hague: Kluwer Law International.s. 421-450. ISBN: $904111212 \mathrm{X}$.

- COHEN, R. - RAI, SH. Global Social Movements. London: Athlone press, Continuum. 2004, 231 s. ISBN: 0826478573.

- COLletTI, L. Rousseau as Critic of Civil Society. From Rousseau to Lenin: Studies in Ideology and Society. New York: NY university press, 1975, $250 \mathrm{~s}$. ISBN: 9780853453505.

- CRAWFORD, J. The Work of the International Law Commission. In CASSESE, A. - GAETA, P. - JONES J. R.W.D. The Rome Statute of the International Criminal Court: A Commentary Oxford: Oxford University Press. 2002, s. 23-34. ISBN: 9780199258987.

- CZEMPIEL, O.E. Kluge Macht-Außenpolitik für das 21. Jahrhundert. Mníchov: C.H.Beck, 1999, 274 s. ISBN 3406453112.

- DAY, B. The Velvet Philosophers. A\&C Black, 1999, 344 s. ISBN: 9781870626422.

- DeLUe, S.M - DALE, T. Political Thinking, Political Theory, and Civil Society. London: Routledge, 2015, 400 s. ISBN: 9781317345534.

- DONNELLY, J. Universal Human Rights in Theory and Practice. 2. vyd. Cornell University Press, 2003, 290 s. ISBN: 0801487765.

- DURHAM, H. Women and Civil Society: NGOs and International Criminal Law. In: ASKIN, K. - KOENIG, D. Women and International Human Rights Law, vol. 3. New York: Transnational Publishers. 2004, 350 s. ISBN: 9781571050946.

- EDWARDS, M. Civil Society. Polity, 2009, 171 s. ISBN: 0745645852.

- FALK, R. The United Nations and Cosmopolitan Democracy: Bad Dream, Utopian Fantasy, Political Project. In: ARCHIBUGI, D. - HELD, D. - KÖHLER, M. 1998. Re-Imagining Political Community: Studies in Cosmopolitan Democracy. Stanford: Stanford University Press, 1998, s. 309-332. ISBN: 9780804735353.

- FLORINI, A.M. - NIHON, K.K.S. The Third Force: The Rise of Transnational Civil Society. Carnegie Endowment, 2000, 295 s. ISBN: 9780870031793.

- FOLEY, M W. - EDWARDS, B. The Paradox of Civil Society In: Journal of Democracy. ISSN: 1045-5736, 1996, vol. 7, s. 38-52.

- GELLER, E. Conditions of Liberty: Civil Society and Its Rivals. London: Hamish Hamilton, 1994, 225 s. ISBN: 0241002206.

- GHILS, P. International Civil Society: International Non-Governmental Organizations in the International System. In: International Social Science Journal. ISSN: 0020-8701, 1992, n. 133, s. 417-31.

- GLASIUS, M. The International Criminal Court: A Global Civil Society Achievement. New York: Routledge, 2006, 186 s. ISBN: 9781134315673. 
- GOLDSHMIDT, M.L. Rousseau on intermediate associations. In: PENNOCK, J.R -CHAPMAN J.W. Voluntary Associations. Transaction Publishers, 2007, 291 S. ISBN: 20079781412841115.

- GRAMSCI, A. Selections from Prison Notebooks of Antonio Gramsci. New York, International Publishers, 1971, 483 s. ISBN: 071780397X.

- HABERMAS, J. Civil Society and the Political Public Sphere. In: Between Facts and Norms: Contributions to a Discourse Theory of Law and Democracy. Cambridge, MA: MIT Press, 1996, 329 s.

- HANN, CH. - DUNN, E. ed. Civil Society: Challenging Western Models. London: Routledge, 1996, 256 s. ISBN: 0415132185.

- HAVEL, V. 1986. The Power of the Powerless: Citizens Against the State in Central-Eastern Europe. In: Soviet Studies. ISSN: 00385859, 1986, vol. 38, n. 4, s. 610-612.

- HONDERICH T. The Oxford Companion to Philosophy. Oxford, Oxford University Press, 2005, 2384 s., ISBN 0-19-866132-0.

- KALDOR, M. Global Civil Society: An Answer to War. Cambridge: Polity. 2003, 189 s. ISBN: 9780745627588.

- KALDOR, M. The Idea of Global Civil Society. In: International Affairs. ISSN 0020-5850, roč. 79, č.3, 2003, s. 583-593.

- KANT, I. Idea of a universal history on a cosmo-political plan. In: SCOTT, J. KANT, I. Idea For A Universal History With A Cosmopolitan Purpose. In REISS, H. S. - Kant, I. Cambridge Texts in the History of Political Thought. 2. vyd. I.Cambridge: Cambridge University Press. 1991, s. 41-53. ISBN 0521398371.

- KANT, I. - REISS, H. - NISBET, H.B. 1991. Perpetual Peace: A Philosophical Sketch. In: KANT, I. 1991. Political Writings. Cambridge Texts in the History of Political Thought. Cambridge: Cambridge University Press, 1991, str. 93-130. 311 s. ISBN: 9780521398374.

- KEANE, J. Global Civil Society? Cambridge: Cambridge University Press, 2003, 220 s. ISBN: $052189462 X$.

- KECK, M. - SIKKINK, K. Activists beyond Borders: Advocacy Networks in International Politics. Ithaca, NY: Cornell University Press. 1998, 228 s. ISBN: 0801484561.

- KECK, M. - SIKKINK, K. Transnational Networks on Violence against Women. In KECK, M. - SIKKINK, K. Activists beyond Borders: Advocacy Networks in International Politics. Ithaca, NY: Cornell University Press. 1998, 228 s. ISBN: 0801484561.

- KEOHANE, R.O. - NYE, J. S. Jr. Power and Interdependence in the Information Age. In Foreign Affairs. ISSN: 0015-7120, 1998, vol. 77, no. 5, s. 81-94.

- KOLAKOWSKI, L. Hope and Hopelessness. In: Survey. 1971, vol. 17, no. 3, s. 37-52.

- KONRÁD, G. Antipolitics: An Essay. Henry Holt, 1987. 243 s. ISBN: 0805003576.

- KREJČÍ, O. Mezinárodní politika. Praha: Ekopress. 2010, 751 s. ISBN 978-8086929-60-6. 
- KUMAR, K. Global Civil Society. In: European Journal of Sociology / Archives Européennes De Sociologie / Europäisches Archiv Für Soziologie, vol. 48, no. 3, 2007, s. 413-434.

- LANGE, L. Feminist Interpretations of Jean-Jacques Rousseau. Penn State Press, 2010, 413 s. ISBN: 0271047070.

- LAYNE, CH. Kant or Cant: The Myth of the Democratic Peace. In: International Security. EISSN: 1531 4804. 2014. vol. 19, no. 2. s. 5-49.

- MARX, K. Capital, Vol. I .London: Lawrence and Wishart., 1867.

- MARX, K. A Contribution to the Critique of Political Economy. Moscow: Progress Publishers. 1859.

- MARX, K. Towards a Critique of Hegel's Philosophy of Rights: Introduction. In: McLELLAN, D. Selected writings. Oxford: Oxford university Press, 1977.

- MiALl, H. - RAMSBOTHAM, O. - WOODHOUSE, T. Contemporary Conflict Resolution. The Prevention, Management and Transformation of Deadly Conflicts. Cambridge: Polity Press, 1999, 288 s. ISBN: 978-0745620350.

- MICHNIK, A. Letters from Prison and Other Essay. University of California Press; London, 1986, 371 s. ISBN: 9780520908581.

- NOONE, G. P. - MOORE, W. D. An introduction to the International Criminal Court. In: Naval Law Review, ISSN: 1049-0272, 1999, vol.46, s. 112.

- OLDFIELD, A. Hegel: Rational Freedom in the ethical Community. In: OLDFIELD, A. Citizenship and Community. Civic Republicanism and the Modern World. London: Routledge, 1990, 208 s. ISBN: 0415048753.

- OST, D. Solidarity and the Politics of Anti-Politics: Opposition and Reform in Poland Since 1968. Temple University Press, 1990, s. 279. ISBN: 0877226555.

- OZ-SALZBERGER, F. Introduction. In: FERGUSON, A. An Essay on the History of Civil Society (ed. Fania Oz-Salzberger). Cambridge: Cambridge University Press, 1995, 322 s. ISBN: 0521447364.

- PELED, Y. Rousseau's Inhibited Radicalism: An Analysis of His Political Thought in Light of His Economic Ideas. In: American Political Science Review. ISSN: 1537-5943, 1980, vol. 74, n. 4, s. 1034-1045.

- PERÉZ - DIAZ, V. The Return of Civil Society. The Emergence of Democratic Spain.Harvard University press, 1998, ISBN: 9780674766891.

- RAWLS, J. Politický liberalizmus. Prešov: Slovacontact, 1997, 304 s. ISBN: 8088876-01-X.

- RICHTER, M. Montesquieu and the Concept of Civil Society. In: The European Legacy. ISSN: 1470-1316, vol. 3, s. 33-41.1998.

- ROUSSEAU, J.J. - BLOOM, A. Politics and the Arts: Letter to M. D'Alembert on the Theatre. Cornell University, 1968. 153 s. ISBN: 9780801490712.

- SARGENT, L.T. Contemporary Political Ideologies. In: KULAŠIK, P. Liberalizmus. Banská Bystrica: UMB 1998.

- SCHABAS, W. A. An Introduction To The International Criminal Court. Cambridge University Press: 2004, 481 s . ISBN: 0521537568.

- SCHECHTER M.G. (ed.) Sources of Innovation in Multilateralism. Basingstoke: Macmillan, 1998, 344 s. ISBN: 978-0-312-21539-2. 
- SHARRATT, S. - KASCHAK, E. Assault on the Soul: Women in the Former Yugoslavia, New York: Haworth Press: 1999, 176 s. ISBN: 9780789007711.

- SMITH A. Theory of Moral Sentiment. Oxford, Clarendon Press. 1976.

- SMITH A. The Wealth of Nations: An Inquiry into the Nature and Causes of the Wealth of Nations. Oxford, Oxford University Press, 1993.

- SMITH J. a kol. (eds) Transnational Social Movements and Global Politics: Solidarity beyond the State. Syracuse: Syracuse University Press: 1997, ISBN: 978-0-8156-2742-5.

- STEAINS, C. 'Gender Issues'. In: Roy S. Lee (ed.), The International Criminal Court: The Making of the Rome Statute; Issues, Negotiations, Results. The Hague: Kluwer Law International 1999, s. 351-391. ISBN: 904111212 X.

- VIROLI, M-HANSON, D. Jean-Jacques Rousseau and the'well-ordered society. Cambridge University Press, 2003, 256 s. ISBN: 0521531381.

\section{Elektronické pramene}

- AHRENS, L. The world court of human rights feasibility study, [online], 201805-10, dostupné na internete: <http://www.rnw.nl/international-justice/article/ un-human-rights-council-faces-same-criticism-its-predecessor>

- BROWN, B. R. Marx and the Foundations of the Critical Theory of Morality and Ethics, In Cultural Logic. 1999, vol. 2, n.2, [online]. 2019-01-10, dostupné na internete:<http://clogic.eserver.org/2-2/brown.html> ISSN: 1097-3087.

- GÁL, E. Liberalizmus dnes. 2005 [online], 2013-10-03 dostupné na internete: $<$ http://www.kritika.sk/pdf/1_2005/2.pdfr>

- GUTMANN, B. Relais et réseaux de la Charte 77 en France, entre 1977 et 1989. In Bulletin de l'Institute Pierre Renouvin IRICE. bipr. 033.0049. roč. 2011/1. č. 33. s. 49- 64. [online], 2019-02-03 dostupné na internete: $<$ https://www.cairn.info/ revue-bulletin-de-1-institut-pierre-renouvin-2011-1-page-49.htm>

- KALDOR, M. $A$ Decade of Humanitarian Intervention: The Role of Global Civil Society. In ANHEIER, H. - GLASIUS, M. - KALDOR, M. Global Civil Society . Oxford: Oxford University Press. s. 109- 144. [online], 2019-11-10, dostupné na internete: <http://www.gcsknowledgebase.org/wp-content/uploads/2001chapter51.pdf $>$

- LEVIATHAN T. H. Locke vs. Hobbes. 2005 [online], cit. 2019-12-28. Dostupné na internete: $\mathrm{http}: / / \mathrm{jim} . \mathrm{com} / \mathrm{hobbes.htm}$

- LOCKE, J. Two Treatises of Government. Oxford university, 1821. [online], 2019-06-07, dostupné na internete: <https://books.google.sk/ books?id=IpYIAAAAQAAJ\&printsec $=$ frontcover $\& \mathrm{hl}=\mathrm{sk} \&$ source $=\mathrm{gbs}$ $\mathrm{atb} \# \mathrm{v}=$ onepage $\& \mathrm{q} \& \mathrm{f}=$ false $>$

- MORAVCSIK, A. Liberalism and International Relations Theory. Paper No. 92-6 Harvard University. [online], 2019-11-11, Dostupné na internete: <http://www. princeton.edu/ amoravcs/library/liberalism_working.pdf $>$

- PIETRZYK-REEVES, D. Civil Society - Conceptual History from Hobbes to Marx. [online]. Marrie Currie working paper no. 1. 2001. [online], 2019-02-12 dostupné na internete: $<$ https://www.academia.edu/7868984/Civil_Society_Conceptual_ History_from_Hobbes_to_Marx> 
- PIETRZYK-REEVES, D. Adam Ferguson's Republicanism. In: Politeja. ISSN: 1733-6716, 2008, vol. 2/1, n. 10/1. s. 67 - 83 . Policy Paper on Sexual and GenderBased Crimes. 2014. [online], 2019-04-21 dostupné na internete: <https://www. icc-cpi.int/iccdocs/otp/OTP-Policy-Paper-on-Sexual-and-Gender-Based-Crimes-June-2014.pdf $>$

- ROUSSEAU, J.J. Du Contract Social. Oeuvres. Ed. orne de fig. (etc.) Didot le jeune, 1793 Zdroj originálu: Rakúska národná knižnica, digitalizované 17. máj 2011. [online], 2019-04-11 dostupné na internete: <https://books.google. sk/books?id=IlZJAAAAcAAJ\&pg=PA204\&dq=jean + jacques + rousseau + soci $\%$ C3\%A9t $\% \mathrm{C} 3 \% \mathrm{~A} 9+$ partielle + associations + partielles\&hl $=$ sk\&sa $=\mathrm{X} \& \mathrm{ved}=0 \mathrm{a}-$ hUKEwiIprW0r7PKAhXEOhQKHT1-B2kQ6AEIJDAB\#v=onepage \&q=jean $\% 20$ jacques $\% 20$ rousseau $\% 20$ soci $\% \mathrm{C} 3 \% \mathrm{~A} 9 \mathrm{t} \% \mathrm{C} 3 \% \mathrm{~A} \%$ 20partielle $\% 20$ associations $\% 20$ partielles\&f $=$ false $>$

- SCHOLTE, J.A. Global Civil Society: Changing the World? In SCHOLTE J.A. CSGR Working Paper No. 31/99, 1999, [online], 2019-04-06 Dostupné na internete: $<$ https://www.unicef.org/socialpolicy/files/Global_Civil_Society_Changing_the World.pdf>

- SWEENEY, D.M. Prospects for the Financing of an International Criminal Court. Institute for Global Policy. 1996. [online], 2018-11-10 dostupné na internete: http:// www.iccnow.org/documents/2PrepCmtFinanceWFMIGP.pdf

- TOCQUEVILle, A. de Democracy in America. G. Adlard, 1839. Harvard: Harvardská univerzita, [online], 2019-7-19 dostupné na internete: <https:// books.google.sk/books? id=e8IOEkLM6KsC\&printsec=frontcover\&dq=democr $\mathrm{acy}+\mathrm{in}+$ america + alexis $+\mathrm{de}+$ tocqueville $\& \mathrm{hl}=\mathrm{sk} \& \mathrm{sa}=\mathrm{X} \& \mathrm{ved}=0$ ahUKEwi_86OqMzKAhUFfiwKHTUMCGgQ6AEIHTAA\#v=onepage $\& \mathrm{q}=$ democracy $\% 20$ in $\% 20$ america\%20alexis $\% 20 \mathrm{de} \% 20$ tocqueville $\& \mathrm{f}=$ false $>$

- WEISS, T a kol. The Rise of Non-State Actors in Global Governance, Opportunities and Limitations. 2013 [online], 2018-04-05 dostupné na internete: $<$ http://acuns. org/wp-content/uploads/2013/11/gg-weiss.pdf>

- ZALESKI, P. Tocqueville on Civilian Society: A Romantic Vision of the Dichotomic Structure of Social Reality.In Archiv Für Begriffsgeschichte, vol. 50, 2008, s. 260-266.

\section{Summary: Theoretical Determination of the Concept of Global Civil Society in Context of the International Relations and the International Law}

The rise of the global activism is a phenomenon that can be perceived through the past 30 years more than ever before. Although the civil society is not a new notion, bearing in mind its still increasing puissance, this notion still lacks a firm and widely accepted definition. To the present day, there is no unified, closed and generally accepted theoretical and conceptual apparatus - at the level of domestic or foreign theorists, but also people from practice, state administration bodies, or civil society itself. Global civil society is a constantly changing entity, a living body that is categorized with great caution even by the academics, emphasising the subjective perception of a specific researched subject matter. Nevertheless, efforts to find a general definition remain. The topic of present study is precisely the theoretical classification of global civil society in the context of the international relations and the international law. 
JUDr. Lubica Saktorová, PhD., LL.M., M.A. Univerzita Mateja Bela Právnická fakulta

Katedra medzinárodného, európskeho práva a právnej komunikácie Komenského 20 97401 Banská Bystrica Slovenská republika lubica.saktorova@umb.sk 